\title{
From inflammaging to healthy aging by dietary lifestyle choices: is epigenetics the key to personalized nutrition?
}

\author{
Katarzyna Szarc vel Szic ${ }^{1}$, Ken Declerck', Melita Vidaković ${ }^{2}$ and Wim Vanden Berghe 1* $^{\text {}^{1}}$
}

\begin{abstract}
The progressively older population in developed countries is reflected in an increase in the number of people suffering from age-related chronic inflammatory diseases such as metabolic syndrome, diabetes, heart and lung diseases, cancer, osteoporosis, arthritis, and dementia. The heterogeneity in biological aging, chronological age, and aging-associated disorders in humans have been ascribed to different genetic and environmental factors (i.e., diet, pollution, stress) that are closely linked to socioeconomic factors. The common denominator of these factors is the inflammatory response. Chronic low-grade systemic inflammation during physiological aging and immunosenescence are intertwined in the pathogenesis of premature aging also defined as 'inflammaging.' The latter has been associated with frailty, morbidity, and mortality in elderly subjects. However, it is unknown to what extent inflammaging or longevity is controlled by epigenetic events in early life. Today, human diet is believed to have a major influence on both the development and prevention of age-related diseases. Most plant-derived dietary phytochemicals and macro- and micronutrients modulate oxidative stress and inflammatory signaling and regulate metabolic pathways and bioenergetics that can be translated into stable epigenetic patterns of gene expression. Therefore, diet interventions designed for healthy aging have become a hot topic in nutritional epigenomic research. Increasing evidence has revealed that complex interactions between food components and histone modifications, DNA methylation, non-coding RNA expression, and chromatin remodeling factors influence the inflammaging phenotype and as such may protect or predispose an individual to many age-related diseases. Remarkably, humans present a broad range of responses to similar dietary challenges due to both genetic and epigenetic modulations of the expression of target proteins and key genes involved in the metabolism and distribution of the dietary constituents. Here, we will summarize the epigenetic actions of dietary components, including phytochemicals, and macro- and micronutrients as well as metabolites, that can attenuate inflammaging. We will discuss the challenges facing personalized nutrition to translate highly variable interindividual epigenetic diet responses to potential individual health benefits/risks related to aging disease.
\end{abstract}

Keywords: Phytochemicals, Oxidative stress, Inflammation, Aging, Epigenetics, Metabolism, Personalized nutrition

\section{Review}

Since people of the twenty-first century live longer, the challenge will be to make these added years as healthy and productive as possible. Societal and medical advances have extended the life of humans. Despite its significance for the well-being of individuals and the

\footnotetext{
* Correspondence: wim.vandenberghe@uantwerpen.be

'Lab Protein Science, Proteomics and Epigenetic Signaling, Department of Biomedical Sciences, University Antwerp, Campus Drie Eiken, Universiteitsplein 1, 2610 Wilrijk, Belgium

Full list of author information is available at the end of the article
}

population as a whole, aging is a poorly understood process. Among the hallmarks of aging are genomic instability, telomere attrition, epigenetic alterations, loss of proteostasis, deregulated nutrient sensing, mitochondrial dysfunction, cellular senescence, stem cell exhaustion, and altered intercellular communication [1]. A large part of the aging phenotype is explained by an imbalance between inflammatory and anti-inflammatory networks $[2,3]$. Levels of inflammatory mediators typically increase with age even in the absence of acute infection or other physiologic stress. While levels are still in the sub-acute 
range, this age-related chronic inflammation underlies many aging-related conditions. According to the oxiinflammaging theory, the aging process is a chronic smoldering oxidative and inflammatory stress that leads to the damage of cellular components, including proteins, lipids, and DNA, contributing to the age-related decline of physiological functions. This is especially evident in cells that regulate homeostasis, such as the nervous, endocrine, and immune systems. It explains their functional losses observed during aging, with a resulting increase in morbidity and mortality [4].

The progressive loss of physiological organismal and cellular integrity is the primary risk factor for major human pathologies, including metabolic syndrome, cancer, diabetes, cardiovascular disorders, and neurodegenerative diseases. Due to an imbalance between energy intake and expenditure, largely attributable to the increased availability of foods with high caloric content coupled with the adoption of a sedentary lifestyle, the continuing increase in obesity and metabolic disorders such as type 2 diabetes and accelerating aging population globally will remain the major contributors to cardiovascular mortality and aging disorders in the next 50 years. This emphasizes the importance of weight management and early intervention with regard to modifiable risk factors in overweight patients. To reduce the burden of cardiometabolic disorders and early onset of aging disorders, promoting exercise with a complementary diet, supplemented with bioactive phytochemicals, is expected to restore immune homeostasis and improve human health $[5,6]$. In the past couple of decades, evidence from prospective observational studies and clinical trials has converged to support the importance of individual nutrients, foods, and dietary patterns in the prevention and management of metabolic disorders [7-12]. With an emphasis on overall diet quality, several dietary patterns such as the Mediterranean diet, low glycemic index diet, moderately low carbohydrate intake, and vegetarian diets can be tailored to personal and cultural food preferences and appropriate calorie needs for weight control, diabetes prevention, and cardiometabolic management [11].

Although genome-wide association studies (GWAS) identified genetic variants that affect hundreds of genes related to energy metabolism involved in metabolic lifestyle diseases and aging, most variants identified so far confer relatively small increments in risk, leaving many questions about the remaining 'missing' heritability, although polygenic disease traits may account for some of these limitations [13-15]. In analogy to the reference human genome sequence which allowed GWAS studies, the NIH Roadmap Epigenomics Consortium generated today the largest collection of human epigenome sequences for epigenome-wide (EWAS) association studies
[16]. From various epigenome-wide (EWAS) association studies, it has become clear that epigenetic changes in response to diet and environmental (stress) conditions complement genetic mutations and contribute to the development and progression of inflammaging diseases such as rheumatoid arthritis, metabolic disorders (obesity, type 2 diabetes), cardiovascular disease, and cancer [17-29]. For example, lifestyle factors and diet have a strong influence on the epigenetic regulation of key products of energy metabolism genes such as leptin (which is responsible for appetite control), insulin receptor (that plays a central role in glucose homeostasis), TNF $\alpha$ (considered as an adipokine because of its role in obesity-related inflammation and modulation of insulin response), and fatty acid synthase (catalyzing fatty acid synthesis) [30]. Accumulating evidence points to an epigenetic basis of the fetal origins of several adult metabolic disorders [31-35]. More particularly, some of the adverse epigenetic effects of lifestyle behaviors maybe rooted in perturbations in utero during pregnancy and during early postnatal life which shape the metabolic phenotype, perhaps across generations, which affect lifelong disease risk [32,36-38].

This review will focus on the epigenetic aspects of 'inflammaging' and whether there are windows of opportunity for nutri-epigenetic intervention with dietary lifestyle choices. Finally, challenges of personalized nutrition will be discussed to translate highly variable interindividual epigenetic diet responses to potential individual health benefits/risks related to diseases associated with aging.

\section{Epigenetics and aging}

Striking links between organismal and cellular aging and epigenome alterations have recently been identified. Age-associated epigenetic changes involve alterations in DNA methylation patterns, posttranslational modification of histones, and chromatin remodeling $[1,39]$. In general, DNA is wrapped around nucleosomes, which are arranged as regularly spaced beads (147 bp DNA/ nucleosome) along the DNA. Typically, nucleosomes consist of a histone $(\mathrm{H})$ octamer of $\mathrm{H} 2 \mathrm{~A} / \mathrm{B}, \mathrm{H} 3$, and H4. The DNA bridging two adjacent nucleosomes is normally bound by the linker histone $\mathrm{H} 1$ and is termed linker DNA. While the core histones are bound relatively tightly to DNA, chromatin is largely maintained by the dynamic association with its architectural proteins (such as transcription cofactors and regulators, heterochromatin protein 1, and high mobility group (HMG) proteins). Before most activators of a gene access their DNA-binding sites, a transition from a condensed heterochromatin ('solenoid-like fiber') to a decondensed euchromatin ('beads on a string') structure appears to take place. Conversely, the acquisition of a more condensed heterochromatin structure is often associated with gene silencing 
[40]. The structural restriction of silenced chromatin on gene expression can be overcome by chromatin writer, reader, and eraser enzyme complexes that remodel nucleosomes along the DNA or reversibly modify histones (through posttranslational modifications, such as histone acetylation, phosphorylation, ubiquitylation, glycosylation, SUMOylation) and establish specific chromatin states involved in transcription [40-42]. Specific sets of histone modifications and/or variants are associated with genes that are actively transcribed or repressed, a phenomenon defined as the 'histone code' [40]. Based on coexisting histone marks and genome-wide ChIP-seq data available within the ENCODE consortium, principal component analysis has reduced the complexity of the histone code into different chromatin states that are associated with developmental and environmental cues [41-44].

DNA methylation is the best-known epigenetic mark $[24,45,46]$. It is catalyzed by two types of DNA methyltransferases (DNMTs): DNMT1 is a maintenance methyltransferase, whereas both DNMT3A and DNMT3B are de novo methyltransferases [47,48]. It is widely accepted that DNMT3A/B are mainly responsible for DNA methylation during development (differentiation) whereas DNMT1 maintains DNA methylation patterns during DNA replication (and cell division). The role of DNMT2 in DNA methylation is minor, its enzymology being largely directed to tRNA. DNA methylation is normally associated with gene inactivation, and it usually occurs in cytosine-phosphate-guanine (CpG) dinucleotides. Alternatively, DNA methylation of transcription factor binding sites which prevents the binding of repressor proteins can, paradoxically, induce gene activation. CpGs are normally methylated when scattered throughout the genome but are mostly unmethylated when clustered as CpG islands at the 5' ends of many genes. Hypermethylation of CpG-rich promoters triggers local histone code modifications that result in a cellular camouflage mechanism which sequesters gene promoters away from transcription factors, causing stable silencing of gene expression. DNA methylation at $\mathrm{CpG}$ dinucleotides occurs upon transfer of S-adenosylmethionine (SAM) on cytosine by DNMTs. Recent results suggest that DNA methylation should be considered as a more dynamic and stochastic process, in which DNA methylation at each site is determined by the local activity of DNMTs, DNA demethylases, and DNA replication enzymes that are controlled by a dynamic network of chromatin marks [49] and signaling pathways [50,51]. For example, the inflammatory mediator prostaglandin $\mathrm{E}(2)$ (PGE(2)) has been shown to exert dynamic DNA methylation changes during cancer inflammation [52,53]. In mammalian cells, the fidelity of maintenance of methylation is $97 \%$ to $99.9 \%$ per mitosis, whereas de novo methylation is as high as $3 \%$ to $5 \%$ per mitosis, thus creating possibilities for dynamic epigenetic changes. Unavoidable errors may accumulate over time following long-term maintenance of epigenetic patterns or occurrence as a result of the accumulation of DNA lesions during aging in both nuclear and mitochondrial DNA caused by increased oxidative stress. Epigenetic errors could explain the stochastic differences in DNA methylation patterns reported in aging monozygotic twins [54,55]. Early studies described an age-associated global hypomethylation, concomitantly with hypermethylation of various tumor suppressor genes and Polycomb target genes [56]. Epigenetic changes accumulated throughout life may also result in the deterioration and reduced regeneration capacity of stem cells [57]. Although in most cases DNA methylation is a stable epigenetic mark, reduced levels of methylation are also observed during development. This net loss of methylation can either occur passively by replication in the absence of functional maintenance methylation pathways or, actively, by indirect removal of methylated cytosines. In mammals, a role for the 5hydroxymethylcytosine $(5-\mathrm{hmC})$ modification in DNA demethylation by ten-eleven translocation (TET) enzymes has been demonstrated as an intermediate in an active DNA demethylation pathway involving DNA repair and 5-hydroxymethylcytosine-specific DNA glycosylase activity $[48,50,58]$.

Of particular interest, reactive oxygen species (ROS) and oxidative stress may affect DNA demethylation by DNA oxidation or TET-mediated hydroxymethylation $[59,60]$. For example, age-related increase in levels of 5$\mathrm{hmC}$ in the brain can be prevented by caloric restriction or upregulation of specific endogenous anti-oxidants [61,62]. Furthermore, nutrients like ascorbic acid can promote DNA demethylation via increased activity of TET enzymes $[63,64]$. In another remarkable study, loss of TET2 and 5-hmC was found to strongly correlate with smooth muscle cell plasticity and the degree of injury in different models of vascular and atherosclerotic disease, in which ROS are critically involved [65]. Alternatively, ROS can influence the methylome by formation of oxidized DNA lesions. Replacement of guanine to 8-hydroxy-2'-deoxy-guanosine (8-OHdG), one of the major DNA oxidative damage by-products, substantially diminishes the binding of methyl-CpG binding proteins and DNMTs and results in heritable epigenetic changes [66-68]. As such, it may be expected that oxidized DNA lesions formed by the hydroxylation of pyrimidines, including 5-methylcytosine (5-mC), interfere with epigenetic signals related to 5-hydroxymethylcytosine (5-hmC) due to their structural similarities [69,70]. Finally, in vitro studies suggest that glutathione (GSH) depletion by redox changes leads to global DNA hypomethylation, possibly through the depletion of SAM [71,72]. 
Tissues and cells of aging organisms also show age-associated changes in histone chromatin marks such as increased histone $\mathrm{H} 4$ lysine(K)16 acetylation, H4K20 trimethylation, or H3K4 trimethylation, as well as decreased H3K9 methylation [73-75]. Age-associated epigenomic changes could be driven by changes in expression of chromatin-modifying or -demodifying enzymes [75-77]. Of particular interest, deletion of components of histone methylation complexes (for H3K4 and for H3K27) extends longevity in nematodes and flies, respectively, and may involve the insulin/IGF-1 signaling pathway [78-81]. It is not yet clear whether aging is a cause or consequence following purely epigenetic changes or alterations affecting metabolic or signaling pathways outside of the nucleus. Importantly, since the activities of histonemodifying enzymes also depend on intracellular levels of essential metabolites (acetyl-coA, Fe, ketoglutarate, $\mathrm{NAD}^{+}$, $\mathrm{S}$-adenosylmethionine), epigenetic changes are tightly linked to global cellular metabolism and energy levels [82-88] (Figure 1). Finally, ROS (such as ${ }^{\circ} \mathrm{O}_{2},{ }^{\circ} \mathrm{OH}, \mathrm{H}_{2} \mathrm{O}_{2}$, $\mathrm{NO}$, and ${ }^{1} \mathrm{O}_{2}$ ) as well as reactive nitrogen intermediates such and NO and reactive nitrogen species (RNS), produced by neutrophils, macrophages, endothelial, and other cells, can indirectly modulate the activity of the epigenetic machinery. For example, ROS were demonstrated to modulate the activity of the Rph1 demethylase specifically at subtelomeres to remodel chromatin and extend lifespan [89].

Although epigenetic modifications previously were thought to be fixed during development and maintained over the lifetime, more recent research provides evidence that epigenetic mechanisms allow rapid adaptations to a changing environment and are responsive to signaling cascades [50,51]. Therefore, epigenetic mechanisms may exacerbate the epidemic of metabolic disease by first contributing to the development of obesity and type 2 diabetes and then passing modifications on to the subsequent generation via transgenerational inheritance [90]. Nevertheless, epigenetic mechanisms might also prevent the development of type 2 diabetes through nutritional intervention therapies [12,34,91,92]. Recent success of therapeutic intervention in chronic inflammatory diseases using epigenetic modifiers such as histone deacetylase (HDAC) and DNMT inhibitors has fuelled interest in methylome profiling of complex diseases [92-103].

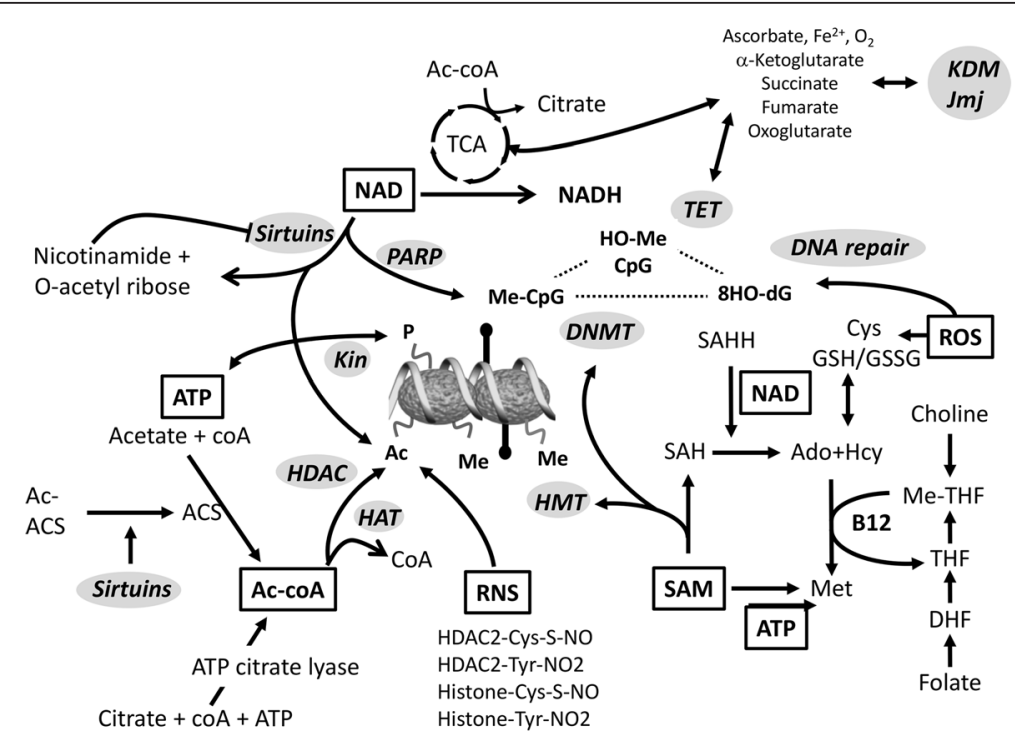

Figure 1 Metabolic pathways generate essential metabolites for chromatin- and DNA-modifying enzymes. NAD, acetyl-coenzyme A (Acetyl-COA), and S-adenosylmethionine (SAM) are elemental for epigenetic control of transcription including methylation of DNA and posttranslational modifications of histones and non-histone chromatin factors (not shown). NAD contributes to transcriptional control mainly via the activity of the protein deacetylase sirtuin, which uses NAD as one of the substrates. Sirtuins are also important for maintaining the activity of the acetyl-coA acetyltransferases. Acetyl-coA is synthesized by acetyl-coA-synthetase (ACS) and ATP-citrate lyase that use acetate and citrate as the precursors, respectively. Citrate is an intermediate/product of the TCA cycle. SAM is the methyl donor for DNA, RNA, histones, and non-histone protein methylation. S-adenosylhomocysteine $(\mathrm{SAH})$ generated in each round of methylation reaction is a potent inhibitor of methyltransferases and has to be cleared by SAH hydrolase (SAHH). NAD is an essential coenzyme for SAHH. Synthesis of methionine from homocystein is achieved through extracting the methyl group from betaine, derived from choline, or 5-methyl-THF, a derivative of folic acid. Metabolism of phospholipids and folic acid may thus indirectly contribute to epigenetic regulation. Likewise, the abundance of NAD and citrate is linked to the cellular energy flux, e.g., the TCA cycle. Changes in the expression of certain genes may therefore be influenced significantly. Abbreviations used: Acetyl-CoA, acetyl-coenzyme A; ACS, acetyl-coA-synthetase; AC-ACS acetylated-ACS; Ado, adenosine; HAT, histone acetyltransferase; Hcy homocysteine; MTases, methyltransferases; NAD, Nicotinamide adenine dinucleotide; ROS, reactive oxygen species, RNS, reactive nitrogen species, SAH, S-adenosyl homocysteine; TCA, tricarboxylic cycle; THF, tetrahydrofolate. 


\section{Crosstalk of inflammation and energy metabolism fuel epigenetic plasticity}

An increasing number of experimental and epidemiological evidence links multifaceted process of aging to systemic low-grade inflammation and disturbances in cellular metabolism and protein homeostasis [104-106]. An efficient autophagic flux, i.e., cellular mechanism for the degradation and recycling of cellular components, is essential for healthy aging and maintenance of cellular homeostasis and links inflammation to metabolic disorders (Figure 2). Autophagy negatively regulates inflammasome activation by maintaining mitochondrial homeostasis. Reciprocally, mitochondrial energy metabolites also regulate aging and autophagy through as-yet-elusive metabolic circuits [105]. Inflammation also profoundly affects the metabolic bioenergetic profile of target cells, promoting aerobic glycolysis, a process called the 'Warburg effect', first described in tumor cells [107]. Different cell conditions require flexible metabolic programs to support unique bioenergetic demands. Metabolic pathways rely on the dynamic balance between anabolic processes to support the synthesis of cellular building blocks and catabolic processes to ensure adequate bioenergetic resources. Beyond nutrient-sensing pathways which control gene transcription and intercellular/extracellular energetic status, nutrient-responsive metabolites, such as ATP, acetyl-CoA, UDP-N-acetylglucosamine (UDP-GlcNAc), and S-adenosyl methionine, mediate crosstalk between metabolism, cellular signaling, and the epigenetic control of transcription programs [108-116] (Figure 3). By operating as indicators of metabolic status, these metabolites serve as substrates for posttranslational modifications, including acetylation, glycosylation, methylation, and phosphorylation, which regulate the activity of metabolic enzymes, signaling pathways, and transcription factors. Because histone-modifying enzymes including kinases, acetyltransferases, and methyltransferases consume key metabolites, the metabolic state of a given cell will also be reflected in the chromatin modification patterns. In this respect, changes in nuclear acetyl-CoA or $\mathrm{NAD}^{+}$levels affect histone acetylation patterns [88,114]. However, the specificity of chromatin changes also depends on the gene-specific recruitment of histone-modifying enzymes to specific chromosomal domains via their interaction with DNA-binding factors, ncRNAs [117-119]. Also, enzymes that use the same metabolite but modify different substrates, such as DNA or histone methyltransferases, may compete with each other leading to either one or the other methylation product. Furthermore, many nutrient metabolites have been shown to have a direct effect on gene expression patterns through binding to nuclear receptors that in turn affect the transcription of the gene they bind to [120]. Interestingly, even transient changes in the nutrition can have a long-lasting impact on gene expression patterns. Heritable 'memory' effects of metabolic disturbances have been demonstrated by the ablation

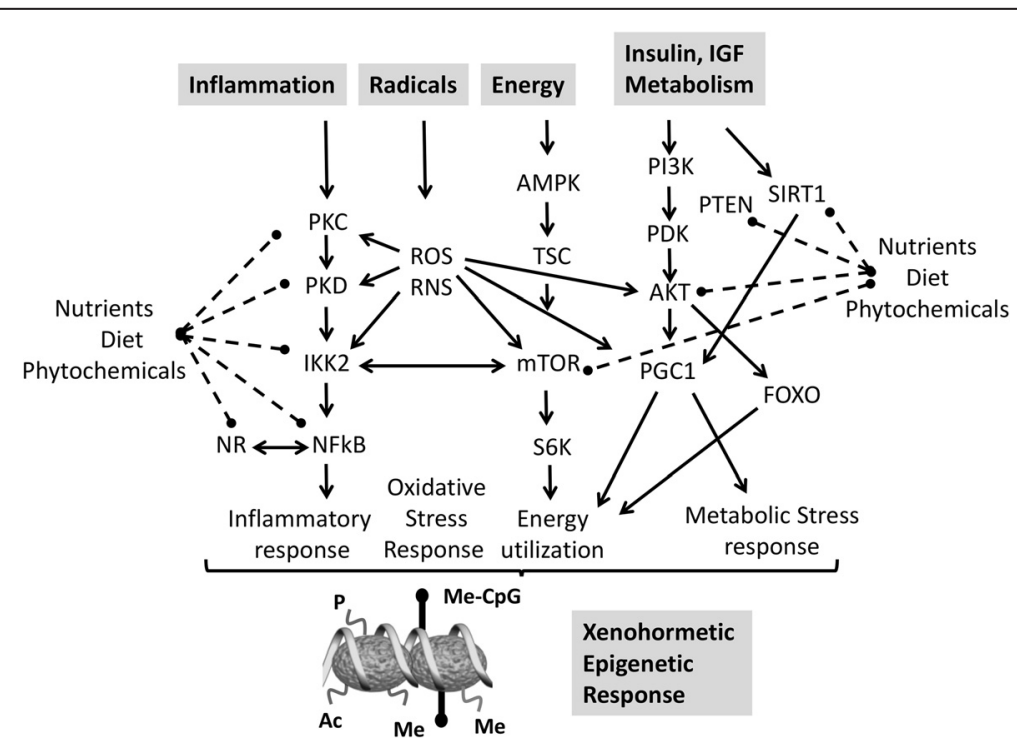

Figure 2 Plant phytochemicals achieve hormesis through multifocal pathway inhibition. Our health strongly benefits from interactions of a large number of plant molecules in our diet with key regulators of mammalian physiology (adapted from [288]). Various plant-derived molecules are synthesized as secondary metabolites in response to stress. During adversity in the context of particular environmental stresses, animals have retained the ability to sense these stress signaling molecules synthesized by their distant ancestors, through enzymes and receptors which regulate inflammation-energy-metabolism pathways to protect and to increase the survival of the organism. Abbreviations used: PKC, protein kinase C; PKD, protein kinase D, IKK2, inhibitor of IKB kinase 2; ROS/RNS, reactive oxygen/nitrogen species; NR, nuclear receptor; AMPK, AMP-activated protein kinase; TSC, tuberous sclerosis complex mTOR, mammalian target of rapamycin; R6SK ribosomal S6 kinase; PI3K, phosphoinositide 3-kinase; PDK, pyruvate dehydrogenase kinase; AKT/PKB, protein kinase B; PGC1, peroxisome proliferator-activated receptor c coactivator 1; SIRT, sirtuin; FOXO, forkhead box O. 


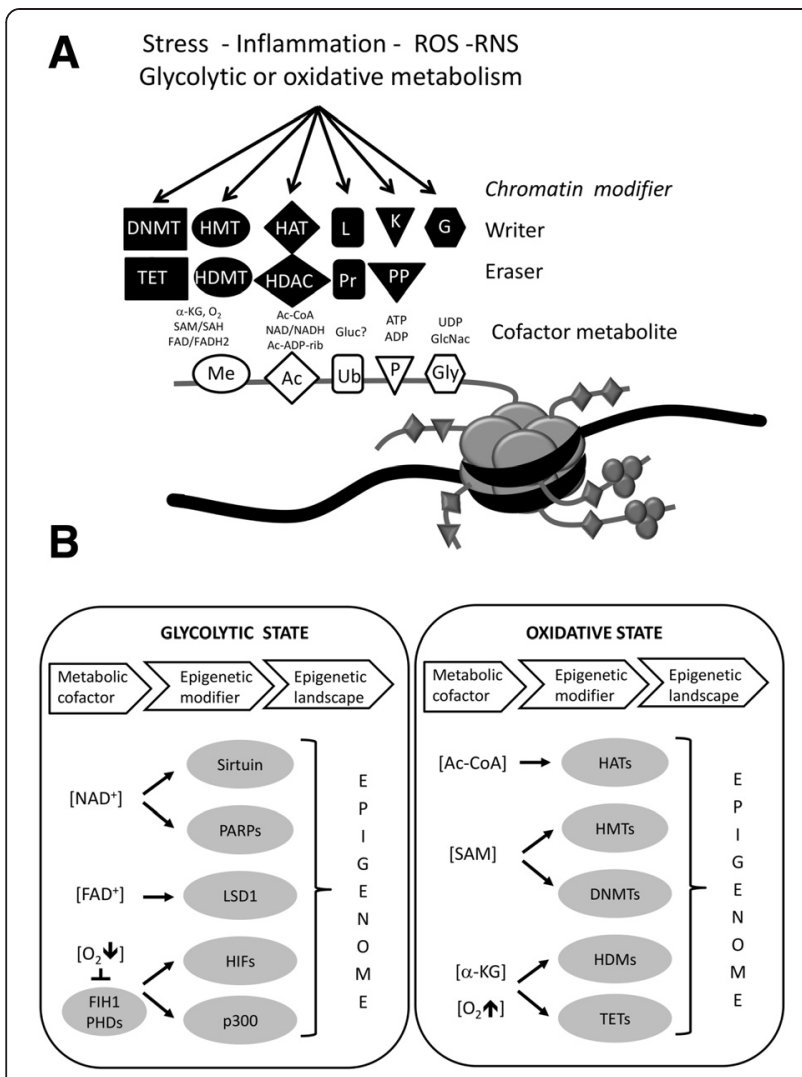

Figure 3 Activity of chromatin modifying writer-eraser enzymes depends on available concentrations of cofactor metabolites and environmental signals. (A) Schematic representation of a nucleosome with extruding histone tails with residues that can be modified by various chromatin writer (i.e., DNA methyltransferase (DNMT), histone methyltransferase (HMT), histone acetylase (HAT), ubiquitin ligase $(L)$, kinase $(K)$, glycosylase $(G))$ or chromatin eraser enzymes (i.e., DNA hydroxymethylase (TET), demethylase (HDMT), deacetylase (HDAC), proteasome (Pr), phosphatase (PP)), resulting in dynamic histone methylation (Me), acetylation (Ac), ubiquitination $(\mathrm{Ub})$, phosphorylation (P), and glycosylation (Gly). These histone modifications have been associated with changes in chromatin organization, gene activation, silencing, and several other nuclear functions (adapted from [338]). (B) Hypothetical model of a glycolytic-oxidative metabolic switch and its possible influence on epigenetic modifiers and the epigenetic landscape (adapted from [339]).

of key epigenetic enzymes such as SIRT1, HDAC6, and KDM3A in models of metabolic disorders [114,116]. These findings pave the way to the development of therapeutic strategies against epigenetic modifier enzymes for the treatment of metabolic and aging disorders [121-123]. Recent theories propose that mitochondria and energy metabolism play a major role in the regulation of health span through Krebs cycle intermediates that shape the epigenetic landscape of chromatin by regulating DNA and histone methylation during the aging process [124,125] (Figure 3B). Of particular interest, the histone variant MacroH2A1.1 but not MacroH2A1.2 was found to bind with high affinity to the SIRT1-metabolite O-acetyl ADP ribose. Upon its overexpression, it ameliorates glucose metabolism and reduces expression of lipidogenic genes and fatty acids [126]. In another study, genetic ablation of histone macro-H2A1 resulted in increased leanness, glucose tolerance, and energy expenditure in mice fed with a highfat diet [127]. Major metabolic changes are also observed in cancers $[72,88,128,129]$. The 'Warburg effect' is accompanied by major alterations in gene expression profile whose causes are likely to be associated with specific chromatin-remodeling events [130-133]. Furthermore, mutated isoforms of the core metabolic enzymes isocitrate dehydrogenase (IDH), succinate dehydrogenase (SDH), and fumarate hydratase $(\mathrm{FH})$ result in accumulation of particular metabolites which inhibit TET enzymes responsible for oxidizing 5-mC, leading to pervasive DNA hypermethylation [111,134-136]. In analogy to 'oncometabolites' whose accumulation triggers aberrant signaling resulting in initiation of carcinogenesis, depletion of 'gerometabolites' was found to drive aging $[137,138]$. Altogether, the cellular metabolism is tightly regulated, and imbalance of energy intake and expenditure contribute to metabolic diseases, cardiovascular diseases, cancer, and other aging diseases. Dynamics and/or reversibility of epigenomic changes in response to altered metabolic states needs to be further investigated.

\section{Nutri-epigenomics: lifelong remodeling of our} epigenomes by nutritional, phytochemical, and metabolic factors

Phytochemicals from plants appear to be crucial to achieve the correct relationship between man and nature - between dietary balance and health (Figure 4). Several polyphenolic compounds, such as resveratrol, tea catechins, and flavonoids, which are commonly found in vegetables, fruits, and plant-derived juices or beverages, exert well-evidenced cardioprotective, neuroprotective, chemopreventive, and anti-inflammatory properties, but, nevertheless, further clinical and epidemiological research is required. Classic proposed mechanisms for the health benefits of phytochemicals are the following: (1) direct antioxidant activity or increase in the expression of antioxidant proteins; (2) attenuation of endoplasmic reticulum stress signaling; (3) blockade of pro-inflammatory cytokines; (4) blockade of transcription factors related to metabolic diseases; (5) induction of metabolic genes expression; and (6) activation of transcription factors that antagonize inflammation [139]. Rather than the chemical conversion of food to energy and body matter of classic metabolism, food is now also a conditioning environment that shapes the activity of the (epi)genome and determines stress adaptive responses, energy metabolism, immune homeostasis, and the physiology of the body [91,140-143]. Human epidemiological studies and appropriately designed dietary 


\section{Nutritional Epigenetics}

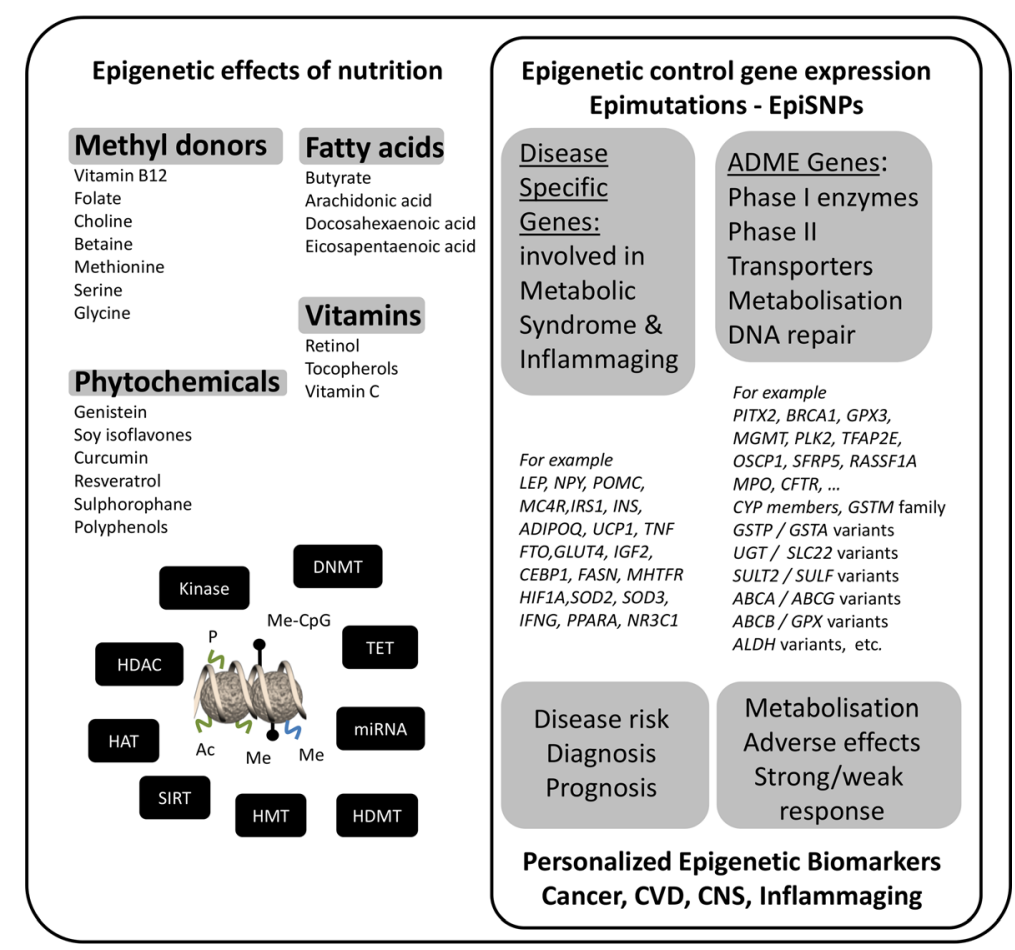

\section{Personalized Nutrition}

Figure 4 Overview of the mechanisms and consequences of epigenetic regulation by nutritional compounds. Modulation of different classes of chromatin writers-erasers by phytochemicals (left panel). Genes encoding absorption, distribution, metabolism, and excretion (ADME) proteins can be epigenetically regulated and thereby determine individual nutritional responses. Epigenetic modification of disease-related genes can contribute to diagnosis (biomarker) as well as disease prevention or progression (right panel).

interventions in animal models have provided considerable evidence to suggest that maternal nutritional imbalance and metabolic disturbances, during critical time windows of development, may have a persistent effect on the health of offspring and may even be transmitted to the next generation [22,144-149]. This has led to the hypothesis of 'fetal programming' and new term 'developmental origin of health and disease' $(\mathrm{DOHaD})[35,150]$. This hypothesis postulates that a nutritional or environmental mismatch between prenatal (in utero gestation) and postnatal life (weaning, infancy, adult life), plays an important causative role in non-communicable diseases, including diabetes, cardiovascular disease, allergy, some forms of cancer, cognitive decline, and affective disorders [21,146,151-156]. The various non-Mendelian features of metabolic disease, cancer, or chronic inflammatory disorders, clinical differences between men and women or monozygotic twins, and fluctuations in the course of the disease are consistent with epigenetic mechanisms in the influence of fetal and/or lifelong nutrition or stochastic events on adult phenotype [22,144-149,157-159].
Thus, lifetime shapes the multitude of epigenomes not only within but also across generations $[22,35,148,160-162]$. Interest in transgenerational epigenetic effects of food components has initially been fuelled by observations in Agouti $\left(\mathrm{A}^{\mathrm{vy}} / \mathrm{a}\right)$ mice fed with a soy polyphenol genistein (GEN), which revealed changes in coat color, related to epigenetic changes in DNA methylation patterns in their offspring and protection against diabetes, obesity, and cancer across multiple generations [163-165]. However, some of these findings were contested in more recent studies with $\mathrm{A}^{\mathrm{vy}} / \mathrm{a}$ mice fed with soy protein isolate, containing comparable amounts of genistein [166]. In another study by Rosenfeld and colleagues, no association between a genistein-based diet and the so-called pseudoagouti, brown phenotype was revealed [167]. Also, only weak transgenerational effects could be observed with soy polyphenols in Daphnia Magna, despite the presence of functional DNMTs [168]. Nevertheless, the honeybee (Apis mellifera) is probably the clearest example of induction of alternative phenotypes and aging epigenotypes by nutrition in early life [169]. Female bees are genetic clones. However, queens are distinct from workers in their morphology, capacity to reproduce, 
behavior, and longevity. The difference between the queen and worker castes lies in the exposure of the genetically identical larvae to royal jelly, an as yet incompletely defined mixture of proteins, amino acids, vitamins, fatty acids, steroids, hormones, lipids, and other nutrients [170-176].

Studies of human populations following famine have suggested that pathologies in later life are dependent on the timing of nutritional insult during pregnancy. Follow up of the Dutch Hunger Winter cohort showed that cardiovascular disease was more prevalent in offspring of mothers who were severely undernourished during the first trimester of their pregnancies in 1944 to 1945 , as compared to those born to mothers whose pregnancies were more advanced at the time of nutritional insult [177-179]. Also, paternal patterns of nutrition during the prepubertal growth period in children in Överkalix, in Sweden, during the nineteenth century are associated with differential risk of early cardiovascular death in their grandchildren $[180,181]$. Today, various epigenetic changes have already been characterized which are involved in atherogenesis [21,22,182-185]. Hypercholesterolemia, obesity, hyperhomocysteinemia, and high glucose are important cardiovascular disease risk factors which are implicated in enhanced inflammatory signaling, and long-lasting effects are driven by epigenetic reprogramming, which promote differentiation of monocytes/ macrophages into more proatherogenic phenotypes [186-192]. Recent evidence suggests that the pathogenetic role of hyperhomocysteinemia in vascular diseases might be mediated via adenosyl-homocystein (Hcy) accumulation and DNA methylation. Hcy competes with SAM (the methyl-group donor) for binding on DNMT, which may lead to passive loss of methylation in replicating DNA. High blood Hcy levels correlate with DNA hypomethylation and atherosclerosis and can lead to a $35 \%$ reduction in DNA methylation status of peripheral blood lymphocytes [193-196]. Similarly, insulin, glucose, folate, or flavanol-rich diets interfere with the methyl donor metabolism and the available pool of SAM, resulting in DNA methylation changes [196-199]. In contrast, very few studies have focused on impact of dietary methyl donors on histone methylation, which is also affected by alterations in SAM/S-adenosylhomocysteine (SAH) ratios [193,200]. As such, specific dietary classes of functional food maybe designed as therapeutic epigenetic modulators in lifestyle disease, such as metabolic disorders (diabetes), cardiovascular disease, asthma/ COPD, and rheumatoid arthritis [91,142,143,201,202].

Epidemiologic and medical anthropological studies have indicated that flavanol-rich diets are inversely associated with cardiovascular risk [203-209]. Locus-specific DNA methylation changes, both hyper- and hypomethylation, have been demonstrated at the promoter of several genes involved in the pathogenesis of atherosclerosis, such as extracellular superoxide dismutase (SOD), hormone receptors (glucocorticoid receptor (GR), estrogen receptor (ER), peroxisome proliferator-activated receptor (PPAR), arylhydrocarbon receptor (AhR), liver X receptor (LXR)), endothelial and inducible nitric oxide synthase (iNOS/eNOS), 15-lipoxygenase (LOX), fibroblast growth factor (FGF)2, hypoxia-inducible factor (HIF) $1 \alpha$, myc, insulator CCCTC binding factor (CTCF), and metalloproteases (MMPs) [189,210-213]. In a proatherogenic murine model, DNAmethylation polymorphisms preceded the appearance of histological signs of atherosclerosis $[187,188]$. Interestingly, involvement of the inducible JMJD3 demethylase was demonstrated to regulate monocyte/macrophage transdifferentiation programs, illustrating that developmental programs are plastic and monocyte lineage differentiation is susceptible to inflammatory pathways and oxidative stress [214]. A role for the JMJD1A demethylase was demonstrated in metabolic gene expression and obesity resistance [215]. Furthermore, it was found that knockdown of the LSD1 demethylase affected monocyte adherence in a proatherogenic diabetic mouse model [216]. This suggests that LSD1 contributes to metabolic memory through long-term changes in gene expression via alterations in chromatin structure [217,218].

Poor maternal nutrition has also been associated with increased risk of type 2 diabetes over several generations in North American Indians [219,220]. Individuals with metabolic syndrome, obesity, type 2 diabetes, and cardiovascular disease may show a lifelong imbalance between energy intake and expenditure due to incorrect epigenetic programming during their early development as a result of placental insufficiency, inadequate maternal nutrition, metabolic disturbances, or neonatal medication [145,219-224].

Recently, evidence emerged that also timing (preconception, pregnancy, lactation, neonatal life, early life, pre-/ post-menopause, puberty) of various dietary exposures may be vitally important in determining health beneficial effects, as epigenetic plasticity changes continually from conception to death [225]. In principle, epigenetic changes occurring during embryonic development will have a much greater impact on the overall epigenetic status of the organism because, as they can be transmitted over consecutive mitotic divisions, alterations occurring in single embryonic stem cells will affect many more cells than those occurring in adult stem and/or somatic cells during postnatal development [147]. Epigenetic plasticity further also depends on other processes such as chromosomal instability, telomere shortening, metabolic cycles, mitochondrial deteriorations, and oscillatory, circadian, or seasonal rhythms of systemic hormone levels (hypothalamic-pituitary-adrenal (HPA) axis) [21,22,93,224-228]. In addition to epigenetic imprinting during crucial periods of development, stochastic or genetically and environmentally 
triggered epigenomic changes (epimutations) occur day after day and accumulate over time, as maximal differences in DNA methylation profiles are observed in aged monozygotic twins with a history of non-shared environments [55,96]. Concerning nutritional transgenerational inheritance, there is increasing evidence in both plants and animals that, following nutritional intervention (caloric, iron and protein restriction, polyphenol-, folate-, micronutrient-, fat-, or carbohydrate-rich diet), maternal diabetes, during pregnancy, and lactation, can affect the following generation(s) [148,153,164,165,229-231]. Although it has long been thought that the epigenomic profile is wiped clean in the embryo shortly after fertilization, with the exception of imprinted genes, methylation clearing is not complete after fertilization and on a global DNA level is reduced to $10 \%[232,233]$ or converted into hydroxymethylcytosine [234]. Alternatively, it cannot be excluded that transgenerationally inherited nutritional effects may also depend on Polycomb proteins [148,235-237], miRNAs, or long noncoding RNAs [19,238-242]. Since hsp90 inhibitors trigger previously hidden morphological phenotypes in the next generation and for several generations thereafter, increasing evidence also supports a 'capacitor' role (i.e., storage of accumulated stress) of hsp90 in buffering transgenerational epigenetic variation during environmental or nutritional stress [243-245].

A next challenge will be to determine which adverse epigenomic marks are reversible by specific diets, drugs, or lifestyle changes [22,116,142,143,146,201,225,231]. Numerous botanical species and plant parts contain a diverse array of polyphenolic phytochemicals which exert health-beneficial effects in man by their anti-inflammatory, anti-oxidant, phytohormone, cardio-protective, cancer preventive, and anti-bacterial properties, by maintaining immune homeostasis (hormesis) [246,247]. Phytochemicals have also successfully been applied for regenerative medicine and cancer stem cell therapy [248-253]. Oxidative stress and inflammatory damage play an important role in epigenetic reprogramming of expression of cytokines, oncogenes, and tumor suppressor genes, thereby setting up a ground for chronic inflammatory diseases and carcinogenesis [254-256]. As such chemoprevention, the strategy to inhibit, retard, or even reverse the epigenetic stage of chronic inflammation is one of the most rational approaches to reduce the global burden of non-communicable aging diseases [30,153,256,257].

Today, various nutritional compounds (including epigallocatechin gallate, resveratrol, genistein, curcumin, isothiocyanates, withaferin A) have been characterized which interfere with enzymatic activity of chromatin writers, readers, or erasers such as DNMT, class I to IV histone deacetylases (HDACs), histone acetyl transferases (HATs), and class III HDAC sirtuins (SIRTs) which modulate inflammatory responses and immunological senescence ([91,140,141,146,155,231,258-269] and references included) (Figure 4). HDACs are zinc metalloproteins which rely on $\mathrm{Zn}^{2+}$ for their activity and are divided into four classes based on their homology with yeast HDACs. Class III HDACs, called sirtuins, are zinc independent but nicotinamide adenine dinucleotide $\left(\mathrm{NAD}^{+}\right)$dependent. Class I to IV HDAC inhibitors characteristically contain a $\mathrm{Zn}^{2+}$ chelating group consisting of a thiolate, thiol, hydroxamate, carboxylate, mercaptoamide, epoxide, or ketone group. Natural HDAC inhibitors can be divided in following groups based on their chemical characteristics: carboxylates, organosulfides, isothiocyanates, hydroamates, cyclic tetrapeptides, and macrocyclic depsipeptides [261]. In contrast to natural HDAC inhibitors, only few natural products (i.e., niacin, dihydrocoumarin) have been identified as inhibitors of class III HDACs. Reciprocally, various natural flavonoids have been identified as activators of class III HDACs (SIRTs). Finally, turmeric and green tea have been identified as sources of natural inhibitors of p300/CBP HAT. Finally, DNMT inhibitors work mainly through one of the following mechanisms, either covalent trapping of DNMT through incorporation into DNA (i.e., nucleoside analogs decitabine, 5-azacytidine), non-covalent blocking of DNMT catalytic active site (i.e., EGCG, parthenolide), interruption of binding site of DNMT to DNA (i.e., procaine), degradation of DNMT (i.e., decitabine), or suppression of DNMT expression (i.e., miRNAs). Furthermore, a number of natural compounds act as multifunctional ligands by simultaneously acting on nuclear hormone receptors and changing activity of histonemodifying enzymes and DNMTs [270-274]. Although health-protective anti-oxidant or anti-inflammatory effects of dietary factors and extracts have frequently been demonstrated in in vitro experiments at concentrations which can never be achieved in vivo, 'epigenetics' might shed a more realistic light on dietary studies, as long life exposure at physiological concentrations could lead to remodeling of the epigenome in a cumulative fashion by repetitive effects on the epigenetic machinery $[160,161,275]$. Particular attention needs to be given to natural compounds which can trigger opposite effects on HDAC/ HAT/DNMT or histone (de)methylase (H(D)MT) depending on the concentration- or cell type-specific metabolization [260,261]. It should also be stressed that it is not known whether all of them can be considered authentic epigenetic modifiers because it has not yet been demonstrated whether the epigenetic modifications which they induce are stable over time. Interestingly, even transient exposure to a specific dietary component can induce long-lasting epigenetic changes in inflammatory gene expression $[218,276]$. Alternatively, compounds may chemically interfere with histone mark interacting protein 
structure motifs (such as chromo-, bromo-, or tudor domains) [277-279].

Besides specific interference of the diet with chromatinmodifying enzymes and DNMTs at particular target genes, global epigenetic changes can also occur following biochemical metabolization of dietary factors, which can deplete cellular pools of acetyl-CoA, $\mathrm{NAD}^{+}$, and methyl donors, resulting in unbalanced DNA methylation and/ or protein acetylation or methylation $[87,266,280]$. For example, diets lacking in substrate or cofactors in methyl donor metabolism can contribute to DNA hypomethylation by impairing synthesis of SAM [194]. This methylation cycle is frequently cited to explain relations between diet and epigenetic changes [193,281]. However, even without nutritional deficiency of methyl groups, impaired synthesis of SAM and perturbed DNA methylation can happen when the need for glutathione (GSH) synthesis increases [282]. Diets or nutritional compounds which affect energy metabolism or mitochondrial respiration can have global epigenetic effects upon changes in $\mathrm{NAD}^{+}$availability and SIRT activity [283]. Since SIRT activation has been linked to longevity (increased lifespan and healthy aging) and mimics a caloric restricted diet, SIRT activators such as resveratrol represent a major class of caloric mimetic phytochemicals which could reverse metabolic disease [280,284-286].

\section{Xenohormetic epigenetic effects of plant secondary metabolites across species: evolutionary role for stress adaptive responses in healthy aging and longevity}

The xenohormesis hypothesis proposes that under stressful conditions, plants synthesize phytochemicals (xenohormetins), which, when incorporated into the heterotroph diet, induce defense responses, leading to an extended lifespan [287]. Most plants contain toxic molecules, in order to prevent pathogen colonization and insect-mediated damage and also to discourage animals from eating them. According to an evolutionary theory of stress adaptation, animals and fungi (heterotrophs) have evolved the ability to respond to stress-induced chemical molecules related to the status of its environment or food supply from other species, to prime a defense response that increases its chances of survival upon subsequent environmental stress challenges. Xenohormesis suggests that the majority of health benefits from phytochemical consumption do not result from responses to mild cellular damage or from their antioxidant properties but rather from the evolutionarily adaptive modulation of the enzymes and receptors of stressresponse pathways in mammals [288]. Therefore, these phytochemicals, working as interspecies transference signals, are preparing living beings for adversity [287]. According to this model, animals facing reduced food availability or other biological stresses have a selective advantage to divert limited resources away from reproduction and growth into maintenance and defense until their offspring have a better chance of survival. Similarly, lifespan extension through caloric restriction may have evolved to promote survival in an environment with poor prospects for reproduction. Also, fasting on alternate days shares similar health benefits as caloric restriction. Perhaps it mimics a natural circumstance in which increasing food uncertainty prepares for possible future starvation conditions. For example, various environmental stress-induced secondary plant metabolites such as resveratrol, butein, and fisetin can induce defense responses in fungi, nematodes, flies, fish, and mice or can extend lifespan by mimicking 'caloric restriction' [288]. These chemical signals regulate the epigenome by modulating metabolic pathways and function of chromatin-modifying enzymes as well as transcription factors that are responsible for recruiting these enzymes.

\section{Interindividual epigenetic variation in diet responses and challenges of personalized nutrition}

From clinical and diet intervention studies, it appears that individuals display different responses to pharmacological nutritional interventions, respectively, that result in variable benefits to particular treatments $[143,289,290]$. Similarly, considerable heterogeneity can be observed in biological aging and chronological age is not a reliable marker for healthy aging [291]. Heterogeneity in responsiveness can obscure associations between dietary intakes and health outcomes and bias the identification of the effects of bioactive phytochemicals in specific subpopulations.

Pharmacogenomic and -kinomic studies demonstrate that for some drugs and/or bioactive nutrients, individuals can be categorized into poor, intermediate, or extensive absorbers or metabolizers and dosing has to be personalized [102,143,160,161,203,292-295]. Various genetic single-nucleotide polymorphisms (SNPs) with known relevance to drug pharmacokinetics, such as detoxification enzymes and transporters, have already been compiled in online databases. For example, several genetic variants exist for genes encoding glutathione S-transferases (GSTs), which play major roles in the metabolism of glucosinolates and bioavailability of isothiocyanates that are present in cruciferous vegetables (broccoli) [296,297]. A significant interindividual variation has also been described for the LDL-cholesterol lowering response to plant sterol consumption, and it is associated with $A B C G 8$ gene polymorphism [298].

However, this is still insufficient to explain the large interindividual variations in therapeutic responses. In recent years, evidence that has accumulated suggests that epigenetic aberrations of key ADME genes (genes related to drug absorption, distribution, metabolism, and excretion) 
involved in the metabolism and distribution of phytochemicals also contribute to interindividual variations in the nutritional response [102,299]. For example, hypermethylation of ADME gene promoters has been observed in cancer tissue, resulting in gene repression of various phase I and II enzymes, including CYP450s and UDP-glucuronosyltransferases, as well as $\mathrm{ABC}$ efflux transporters [300-302] (Figure 4). The introduction or removal of CpG dinucleotides at SNPs (CpG-SNPs, epimutations) may represent a potential mechanism through which SNPs affect gene function via epigenetic processes [31,303]. Conversely, epigenetic changes could increase susceptibility to genetic point mutations [304]. This indicates a complex interrelationship between genetic and epigenetic variations in different diet-related disease phenotypes [31,304-309]. Personalized nutrition is an increasingly recognized paradigm in nutrition research. Therefore, some population subgroups may gain more benefit than others from the consumption of plant foods and their bioactives. The further determination of environmental factors responsible for interindividual variations in the endocrine system, epigenetic profiles, and microbiome communities and the identification of 'susceptibility profiles' in response to plant bioactive consumption could lead to targeted dietary advice and use of functional foods customized for different population subgroups [143,310-312]. In contrast to prominent quantitative epigenetic changes at tumor suppressor genes $(>60 \%$ increase of DNA methylation) associated with cancer, more subtle epigenetic changes are typically observed in cardiometabolic disorders $(<20 \%)$ [312-320]. To reverse such subtle changes, several nutrients and bioactive food compounds may be preferred over toxic antineoplastic epigenetic drugs [91,121,142,143,321-327]. This will encourage the characterization of robust epigenetic dietary biomarkers and design of functional foods that could help to combat or prevent inflammaging-related metabolic diseases.

\section{Conclusions}

The phenotype of an individual is the result of complex ongoing gene-environment interactions in the present, past, and ancestral environments, responsible for lifelong remodeling of our epigenomes. In recent years, several studies have demonstrated that disruption of epigenetic mechanisms can alter immune function and that epimutations not only contribute to certain cancers but also to lifestyle diseases such as type 2 diabetes, allergies, cardiovascular disease, and rheumatoid arthritis, as well as unhealthy aging. Various replication-dependent and -independent epigenetic mechanisms are involved in developmental programming, a lifelong intertwined process of monitoring and responding to environmental changes, and the transmission of transgenerational effects. It is likely that improved understanding of epigenetic processes will allow us to manipulate the epigenome which represents a reversible source of biological variation $[328,329]$. We believe that herein resides a great potential for chemoprevention, alleviation of chronic inflammatory disorders, and healthy aging. Much attention is currently focused on the modulation of hyper/hypomethylation of key inflammatory genes by dietary factors as an effective approach to chronic inflammatory disease management and general health benefits [146,155,231,259-266]. In this respect, 'Let food be your epigenetic medicine' could represent a novel interpretation of what Hippocrates said twenty-five centuries ago. As such, it will be a challenge for future nutritional research to identify novel epigenetic targets that promote healthy aging [247,330-335]. Given several encouraging trials, prevention and therapy of age- and lifestyle-related diseases by individualized tailoring of optimal epigenetic diets or supplements are conceivable. However, these interventions will require intense efforts to identify health beneficial relationships in intra- (age/tissue/cell-type specific) and interindividual variation of epigenetic, genetic, and environment interactions [35,310,336,337].

In conclusion, 'inflammaging' disorders as well as dietary lifestyle reveal a dazzling complexity of epigenetic changes during lifetime. To prevent or to reverse adverse epigenetic alterations associated with multifactorial aging diseases, combinatorial therapeutic and/or nutritional approaches will be necessary to modulate different classes of chromatin modifiers. Future research needs to evaluate the optimal dose and exposure window during gestation in utero, post-natal early life, prepuberty, and adult life for specific dietary composition to elicit maximal epigenetic benefits against inflammaging and improve the overall quality of life of the human population [35,309,324-327].

\section{Abbreviations}

5-hmc: 5-hydroxymethylcytosine; 5-mC: 5-methylcytosine; 8-OHdG: 8-hydroxy-2'-deoxy-guanosine; ADME: absorption, distribution, metabolism, excretion; AhR: arylhydrocarbon receptor; CpG: cytosine-phosphate-guanine; CTCF: insulator CCCTC binding factor; DNMT: DNA methyltransferase; DOHD: developmental origin of health and disease; eNOS/iNOS: endothelial and inducible nitric oxide synthase; ER: estrogen receptor; FGF: fibroblast growth factor; FH: fumarate hydratase; GR: glucocorticoid receptor;

GSH: glutathione; HAT: histon acetyl transferases; HDAC: histone deacetylase; HIF: hypoxia-inducible factor; HMT: histone methyltransferases;

HPA: hypothalamic-pituitary-adrenal; IDH: isocitrate dehydrogenase; IGF: insulin growth factor; JMJD: jumonji domain; KDM: lysine demethylase; LOX: lipoxygenase; LXR: liver X receptor; MMP: metalloproteases: ncRNAs: noncoding RNA; PDK: pyruvate dehydrogenase kinase; PGE2: prostaglandin E2; PPAR: peroxisome proliferator-activated receptor; RNS: reactive nitrogen species; ROS: reactive oxygen species; SAM: S-adenosylmethionine; SDH: succinate dehydrogenase; SIRT: sirtuin; SNP: single nucleotide polymorphism; SOD: superoxide dismutase; TET: ten-eleven translocation; UDP-GICNAc: UDP-N-acetylglucosamine.

\section{Competing interests}

The authors declare that they have no competing interests. 


\section{Authors' contributions}

All authors contributed to the content. All authors read and approved the final manuscript.

\section{Acknowledgements}

This work has been supported by COST TD0905: Epigenetics from bench to bedside; COST CM1406: Epigenetic Chemical Biology; COST FA1403: Interindividual variation in response to consumption of plant food bioactives, and FWO research grants. MV wishes to recognize the assistance of the Serbian Ministry of Education, Science and Technological Development, Grant 173020 and bilateral project 'Pavle Savić' (451-03-3455/2013-09/12/02) We thank all lab members for helpful discussions.

\section{Author details}

'Lab Protein Science, Proteomics and Epigenetic Signaling, Department of Biomedical Sciences, University Antwerp, Campus Drie Eiken, Universiteitsplein 1, 2610 Wilrijk, Belgium. ²Department of Molecular Biology, Institute for Biological Research, University of Belgrade, Bulevar Despota Stefana 142, 11060 Belgrade, Serbia.

\section{Received: 16 November 2014 Accepted: 9 March 2015} Published online: 25 March 2015

\section{References}

1. López-Otín C, Blasco MA, Partridge L, Serrano M, Kroemer G. The hallmarks of aging. Cell. 2013;153(6):1194-217.

2. Baylis D, Bartlett DB, Patel HP, Roberts HC. Understanding how we age: insights into inflammaging. Longev Healthspan. 2013;2(1):8.

3. Franceschi C, Capri M, Monti D, Giunta S, Olivieri F, Sevini F, et al. Inflammaging and anti-inflammaging: a systemic perspective on aging and longevity emerged from studies in humans. Mech Ageing Dev. 2007;128(1):92-105.

4. De la Fuente $M$, Miquel J. An update of the oxidation-inflammation theory of aging: the involvement of the immune system in oxi-inflammaging. Curr Pharm Des. 2009;15(26):3003-26.

5. Ling C, Ronn T. Epigenetic adaptation to regular exercise in humans. Drug Discov Today. 2014;19(7):1015-8.

6. Denham J, O'Brien BJ, Marques FZ, Charchar FJ. Changes in the leukocyte methylome and its effect on cardiovascular related genes after exercise. J Applied Physiol. 2014. doi:10.1152/japplphysiol.00878.2014.

7. Santoro A, Pini E, Scurti M, Palmas G, Berendsen A, Brzozowska A, et al. Combating inflammaging through a Mediterranean whole diet approach: the NU-AGE project's conceptual framework and design. Mech Ageing Dev. 2014:136-137:3-13.

8. Zamora-Ros R, Forouhi NG, Sharp SJ, Gonzalez CA, Buijsse B, Guevara M, et al. Dietary intakes of individual flavanols and flavonols are inversely associated with incident type 2 diabetes in European populations. J Nutrit. 2013;144(3):335-43.

9. Beaudoin C, Attig L, Vigé A, Gabory A, Karimi M, Beauger A, et al. Dietary alleviation of maternal obesity and diabetes: increased resistance to diet-induced obesity transcriptional and epigenetic signatures. PLoS One. 2013;8(6):e66816.

10. Berendsen A, Santoro A, Pini E, Cevenini E, Ostan R, Pietruszka B, et al. A parallel randomized trial on the effect of a healthful diet on inflammageing and its consequences in European elderly people: design of the NU-AGE dietary intervention study. Mech Ageing Dev. 2013;134(11-12):523-30.

11. Van Gaal LF, Maggioni AP. Overweight, obesity, and outcomes: fat mass and beyond. Lancet. 2014;383(9921):935-6.

12. Ley $\mathrm{SH}$, Hamdy $\mathrm{O}$, Mohan $\mathrm{V}$, Hu FB. Prevention and management of type 2 diabetes: dietary components and nutritional strategies. Lancet. 2014;383 (9933):1999-2007.

13. Manolio TA, Collins FS, Cox NJ, Goldstein DB, Hindorff LA, Hunter DJ, et al. Finding the missing heritability of complex diseases. Nature. 2009;461 (7265):747-53.

14. Maher B. Personal genomes: the case of the missing heritability. Nature. 2008;456(7218):18-21.

15. Hinney A, Vogel Cl, Hebebrand J. From monogenic to polygenic obesity: recent advances. Eur Child Adolesc Psychiatry. 2010;19(3):297-310.

16. Roadmap Epigenomics C, Kundaje A, Meuleman W, Ernst J, Bilenky M, Yen $A$, et al. Integrative analysis of 111 reference human epigenomes. Nature. 2015;518(7539):317-30.
17. Miller RL, Ho SM. Environmental epigenetics and asthma: current concepts and call for studies. Am J Respir Crit Care Med. 2008:177(6):567-73.

18. Villeneuve LM, Natarajan R. The role of epigenetics in the pathology of diabetic complications. Am J Physiol Renal Physiol. 2010;299(1):F14-25.

19. Guil S, Esteller M. DNA methylomes, histone codes and miRNAs: tying it all together. Int J Biochem Cell Biol. 2009;41(1):87-95.

20. Schwartz DA. Epigenetics and environmental lung disease. Proc Am Thorac Soc. 2010;7(2):123-5.

21. Gluckman PD, Hanson MA, Cooper C, Thornburg KL. Effect of in utero and early-life conditions on adult health and disease. N Engl J Med. 2008;359(1):61-73.

22. Godfrey KM, Gluckman PD, Hanson MA. Developmental origins of metabolic disease: life course and intergenerational perspectives. Trends Endocrinol Metab. 2010;21(4):199-205

23. Davalos V, Esteller M. MicroRNAs and cancer epigenetics: a macrorevolution. Curr Opin Oncol. 2010;22(1):35-45.

24. Esteller M. Cancer epigenomics: DNA methylomes and histone-modification maps. Nat Rev Genet. 2007;8(4):286-98.

25. Esteller M. Epigenetics in cancer. N Engl J Med. 2008;358(11):1148-59.

26. Paul DS, Beck S. Advances in epigenome-wide association studies for common diseases. Trends Mol Med. 2014:20(10):541-3.

27. Dick KJ, Nelson CP, Tsaprouni L, Sandling JK, Aissi D, Wahl S, et al. DNA methylation and body-mass index: a genome-wide analysis. Lancet. 2014;383(9933):1990-8

28. McAllister EJ, Dhurandhar NV, Keith SW, Aronne LJ, Barger J, Baskin M, et al. Ten putative contributors to the obesity epidemic. Crit Rev Food Sci Nutr. 2009;49(10):868-913.

29. Mill J, Heijmans BT. From promises to practical strategies in epigenetic epidemiology. Nat Rev Genet. 2013;14(8):585-94.

30. Milagro Fl, Mansego ML, De Miguel C, Martinez JA. Dietary factors, epigenetic modifications and obesity outcomes: progresses and perspectives. Mol Aspects Med. 2013:34(4):782-812.

31. Teh AL, Pan H, Chen L, Ong ML, Dogra S, Wong J, et al. The effect of genotype and in utero environment on interindividual variation in neonate DNA methylomes. Genome Res. 2014;24(7):1064-74.

32. Susiarjo M, Bartolomei MS. Epigenetics: you are what you eat, but what about your DNA? Science. 2014;345(6198):733-4.

33. Radford EJ, Ito M, Shi H, Corish JA, Yamazawa K, Isganaitis $E$, et al. In utero effects: in utero undernourishment perturbs the adult sperm methylome and intergenerational metabolism. Science. 2014;345(6198):1255903.

34. Lehnen $H$, Zechner $U$, Haaf T. Epigenetics of gestational diabetes mellitus and offspring health: the time for action is in early stages of life. Mol Hum Reprod. 2013;19(7):415-22.

35. Topol EJ. Individualized medicine from prewomb to tomb. Cell. 2014;157 (1):241-53

36. Barouki R, Gluckman PD, Grandjean P, Hanson M, Heindel JJ. Developmental origins of non-communicable disease: implications for research and public health. Environ Health. 2012;11:42

37. Adamo KB, Ferraro ZM, Brett KE. Can we modify the intrauterine environment to halt the intergenerational cycle of obesity? Int J Environ Res Public Health. 2012:9(4):1263-307.

38. Martínez D, Pentinat T, Ribó S, Daviaud C, Bloks Vincent W, Cebrià J, et al. In utero undernutrition in male mice programs liver lipid metabolism in the second-generation offspring involving altered Ixra DNA methylation. Cell Metab. 2014;19(6):941-51.

39. Teschendorff AE, West J, Beck S. Age-associated epigenetic drift: implications, and a case of epigenetic thrift? Hum Mol Genet. 2013:22(R1):R7-15.

40. Chi $P$, Allis CD, Wang GG. Covalent histone modifications - miswritten, misinterpreted and mis-erased in human cancers. Nat Rev. 2010;10(7):457-69.

41. Ernst J, Kellis M. Discovery and characterization of chromatin states for systematic annotation of the human genome. Nat Biotechnol. 2010;28 (8):817-25.

42. Ernst J, Kheradpour P, Mikkelsen TS, Shoresh N, Ward LD, Epstein CB, et al. Mapping and analysis of chromatin state dynamics in nine human cell types. Nature. 2011;473(7345):43-9.

43. Zhu J, Adli M, Zou JY, Verstappen G, Coyne M, Zhang X, et al. Genome-wide chromatin state transitions associated with developmental and environmental cues. Cell. 2013:52(3):642-5.

44. Dunham I, Kundaje A, Aldred SF, Collins PJ, Davis CA, Doyle F, et al. An integrated encyclopedia of DNA elements in the human genome. Nature. 2012:489(7414):57-74. 
45. Bird A. DNA methylation patterns and epigenetic memory. Genes Dev. 2002;16(1):6-21.

46. Schubeler D. Function and information content of DNA methylation. Nature. 2015;517(7534):321-6.

47. Jones PA, Liang G. Rethinking how DNA methylation patterns are maintained. Nat Rev Genet. 2009;10(11):805-11.

48. Law JA, Jacobsen SE. Establishing, maintaining and modifying DNA methylation patterns in plants and animals. Nat Rev Genet. 2010;11(3):204-20.

49. Guo X, Wang L, Li J, Ding Z, Xiao J, Yin X, et al. Structural insight into autoinhibition and histone $\mathrm{H3}$-induced activation of DNMT3A. Nature. 2015;517(7536):640-4.

50. Jeltsch A, Jurkowska RZ. New concepts in DNA methylation. Trends Biochem Sci. 2014;39(7):310-8.

51. Deplus R, Blanchon L, Rajavelu A, Boukaba A, Defrance M, Luciani J, et al. Regulation of DNA methylation patterns by CK2-mediated phosphorylation of DNMT3a. Cell Rep. 2014;8(3):743-53.

52. Huang SK, Scruggs AM, Donaghy J, McEachin RC, Fisher AS, Richardson BC, et al. Prostaglandin E(2) increases fibroblast gene-specific and global DNA methylation via increased DNA methyltransferase expression. FASEB J. 2012;26(9):3703-14.

53. Xia D, Wang D, Kim SH, Katoh H, DuBois RN. Prostaglandin E2 promotes intestinal tumor growth via DNA methylation. Nat Med. 2012;18(2):224-6.

54. Hannum G, Guinney J, Zhao L, Zhang L, Hughes G, Sadda S, et al. Genome-wide methylation profiles reveal quantitative views of human aging rates. Mol Cell. 2013;49(2):359-67.

55. Fraga MF, Ballestar E, Paz MF, Ropero S, Setien F, Ballestar ML, et al. Epigenetic differences arise during the lifetime of monozygotic twins. Proc Natl Acad Sci U S A. 2005;102(30):10604-9.

56. Maegawa S, Hinkal G, Kim HS, Shen L, Zhang L, Zhang J, et al. Widespread and tissue specific age-related DNA methylation changes in mice. Genome Res. 2010;20(3):332-40.

57. Oh J, Lee YD, Wagers AJ. Stem cell aging: mechanisms, regulators and therapeutic opportunities. Nat Med. 2014;20(8):870-80.

58. Delatte B, Deplus R, Fuks F. Playing TETris with DNA modifications. EMBO J. 2014;33(11):1198-211.

59. Wang L, Chia NC, Lu X, Ruden DM. Hypothesis: environmental regulation of 5-hydroxymethylcytosine by oxidative stress. Epigenetics. 2011;6(7):853-6.

60. Perillo B, Ombra MN, Bertoni A, Cuozzo C, Sacchetti S, Sasso A, et al. DNA oxidation as triggered by H3K9me2 demethylation drives estrogen-induced gene expression. Science. 2008;319(5860):202-6.

61. Chouliaras L, van den Hove DL, Kenis G, Keitel S, Hof PR, van Os J, et al. Age-related increase in levels of 5 -hydroxymethylcytosine in mouse hippocampus is prevented by caloric restriction. Curr Alzheimer Res. 2012;9(5):536-44.

62. Li Y, Daniel M, Tollefsbol TO. Epigenetic regulation of caloric restriction in aging. BMC Med. 2011;9(1):98.

63. Blaschke K, Ebata KT, Karimi MM, Zepeda-Martinez JA, Goyal P, Mahapatra S, et al. Vitamin C induces Tet-dependent DNA demethylation and a blastocyst-like state in ES cells. Nature. 2013;500(7461):222-6.

64. Yin R, Mao SQ, Zhao B, Chong Z, Yang Y, Zhao C, et al. Ascorbic acid enhances Tet-mediated 5-methylcytosine oxidation and promotes DNA demethylation in mammals. J Am Chem Soc. 2013;135(28):10396-403.

65. Liu R, Jin Y, Tang WH, Qin L, Zhang X, Tellides G, et al. Ten-eleven translocation-2 (TET2) is a master regulator of smooth muscle cell plasticity. Circulation. 2013;128(18):2047-57.

66. Valinluck V, Tsai HH, Rogstad DK, Burdzy A, Bird A, Sowers LC. Oxidative damage to methyl- $\mathrm{CpG}$ sequences inhibits the binding of the methyl-CpG binding domain (MBD) of methyl-CpG binding protein 2 (MeCP2). Nucleic Acids Res. 2004;32(14):4100-8.

67. Valinluck V, Sowers LC. Endogenous cytosine damage products alter the site selectivity of human DNA maintenance methyltransferase DNMT1. Cancer Res. 2007;67(3):946-50

68. Langie SA, Kowalczyk P, Tomaszewski B, Vasilaki A, Maas LM, Moonen EJ, et al. Redox and epigenetic regulation of the APE1 gene in the hippocampus of piglets: the effect of early life exposures. DNA Repair (Amst). 2014:18:52-62.

69. Lewandowska J, Bartoszek A. DNA methylation in cancer development, diagnosis and therapy - multiple opportunities for genotoxic agents to act as methylome disruptors or remediators. Mutagenesis. 2011;26(4):475-87.

70. Dao T, Cheng RY, Revelo MP, Mitzner W, Tang W. Hydroxymethylation as a novel environmental biosensor. Curr Environ Health Rep. 2014;1(1):1-10.
71. Niedzwiecki MM, Hall MN, Liu X, Oka J, Harper KN, Slavkovich V, et al. Blood glutathione redox status and global methylation of peripheral blood mononuclear cell DNA in Bangladeshi adults. Epigenetics. 2013;8(7):730-8.

72. Hitchler MJ, Domann FE. Redox regulation of the epigenetic landscape in cancer: a role for metabolic reprogramming in remodeling the epigenome. Free Radic Biol Med. 2012;53(11):2178-87.

73. Fraga MF, Esteller M. Epigenetics and aging: the targets and the marks. Trends Genet. 2007:23(8):413-8.

74. Han S, Brunet A. Histone methylation makes its mark on longevity. Trends Cell Biol. 2012;22(1):42-9.

75. Wood JG, Helfand SL. Chromatin structure and transposable elements in organismal aging. Front Genet. 2013;4:274.

76. Kreiling JA, Tamamori-Adachi M, Sexton AN, Jeyapalan JC, Munoz-Najar U, Peterson AL, et al. Age-associated increase in heterochromatic marks in murine and primate tissues. Aging Cell. 2011;10(2):292-304.

77. Feser J, Tyler J. Chromatin structure as a mediator of aging. FEBS Lett. 2011:585(13):2041-8

78. Jin C, Li J, Green CD, Yu X, Tang X, Han D, et al. Histone demethylase UTX-1 regulates $C$. elegans life span by targeting the insulin/GF-1 signaling pathway. Cell Metab. 2011;14(2):161-72.

79. Wood JG, Hillenmeyer S, Lawrence C, Chang C, Hosier S, Lightfoot W, et al. Chromatin remodeling in the aging genome of Drosophila. Aging Cell. 2010:9(6):971-8.

80. Maures TJ, Greer EL, Hauswirth AG, Brunet A. The H3K27 demethylase UTX-1 regulates $C$. elegans lifespan in a germline-independent, insulin-dependent manner. Aging Cell. 2011;10(6):980-90.

81. Greer EL, Maures TJ, Ucar D, Hauswirth AG, Mancini E, Lim JP, et al. Transgenerational epigenetic inheritance of longevity in Caenorhabditis elegans. Nature. 2011:479(7373):365-71.

82. Luo J, Kuo MH. Linking nutrient metabolism to epigenetics. Cell Sci Rev. 2009;6:49-54.

83. Bellet MM, Sassone-Corsi P. Mammalian circadian clock and metabolism the epigenetic link. J Cell Sci. 2010;123(Pt 22):3837-48.

84. Chang J, Zhang B, Heath H, Galjart N, Wang X, Milbrandt J. Nicotinamide adenine dinucleotide (NAD)-regulated DNA methylation alters CCCTCbinding factor (CTCF)/cohesin binding and transcription at the BDNF locus. Proc Natl Acad Sci U S A. 2010;107(50):21836-41.

85. Wallace DC. Bioenergetics and the epigenome: interface between the environment and genes in common diseases. Dev Disabil Res Rev. 2010;16 (2):114-9.

86. Wallace DC. The epigenome and the mitochondrion: bioenergetics and the environment [corrected]. Genes Dev. 2010;24(15):1571-3.

87. Ladurner AG. Chromatin places metabolism center stage. Cell. 2009;138(1):18-20.

88. Simpson NE, Tryndyak VP, Pogribna M, Beland FA, Pogribny IP. Modifying metabolically sensitive histone marks by inhibiting glutamine metabolism affects gene expression and alters cancer cell phenotype. Epigenetics. 2012; $7(12): 1413-20$.

89. Mirisola MG, Longo VD. A radical signal activates the epigenetic regulation of longevity. Cell Metab. 2013;17(6):812-3.

90. Einstein FH. Multigenerational effects of maternal undernutrition. Cell Metab. 2014:19(6):893-4.

91. Vanden Berghe W. Epigenetic impact of dietary polyphenols in cancer chemoprevention: lifelong remodeling of our epigenomes. Pharmacol Res. 2012;65(6):565-76

92. Toperoff G, Aran D, Kark JD, Rosenberg M, Dubnikov T, Nissan B, et al. Genome-wide survey reveals predisposing diabetes type 2-related DNA methylation variations in human peripheral blood. Hum Mol Genet. 2012;21 (2):371-83.

93. Jones PA. Moving AHEAD with an international human epigenome project. Nature. 2008:454(7205):711-5.

94. Altucci L, Stunnenberg HG. Time for epigenetics. Int I Biochem Cell Biol. 2009:41(1):2-3.

95. Liu Y, Aryee MJ, Padyukov L, Fallin MD, Hesselberg E, Runarsson A, et al. Epigenome-wide association data implicate DNA methylation as an intermediary of genetic risk in rheumatoid arthritis. Nat Biotechnol. 2013;31(2):142-7.

96. Christensen BC, Houseman EA, Marsit CJ, Zheng S, Wrensch MR, Wiemels $J \mathrm{~L}$, et al. Aging and environmental exposures alter tissue-specific DNA methylation dependent upon CpG island context. PLoS Genet. 2009;5(8):e1000602.

97. Langevin SM, Houseman EA, Christensen BC, Wiencke JK, Nelson HH, Karagas MR, et al. The influence of aging, environmental exposures and 
local sequence features on the variation of DNA methylation in blood. Epigenetics. 2011;6(7):908-19.

98. Tan Q, Christiansen L, Thomassen M, Kruse TA, Christensen K. Twins for epigenetic studies of human aging and development. Ageing Res Rev. 2013;12(1):182-7.

99. Zhao J, Forsberg CW, Goldberg J, Smith NL, Vaccarino V. MAOA promoter methylation and susceptibility to carotid atherosclerosis: role of familial factors in a monozygotic twin sample. BMC Med Genet. 2012;13:100.

100. Simo-Riudalbas L, Esteller M. Targeting the histone orthography of cancer: drugs for writers, erasers and readers. Br J Pharmacol. 2014; 2014. doi:10.1111/bph.12844.

101. Helin K, Dhanak D. Chromatin proteins and modifications as drug targets. Nature. 2013;502(7472):480-8.

102. Ivanov M, Barragan I, Ingelman-Sundberg M. Epigenetic mechanisms of importance for drug treatment. Trends Pharmacol Sci. 2014;35(8):384-96

103. Falkenberg $\mathrm{K}$, Johnstone R. Histone deacetylases and their inhibitors in cancer, neurological diseases and immune disorders. Nat Rev Drug Discov. 2014;13:673-91.

104. Eisenberg T, Schroeder S, Buttner S, Carmona-Gutierrez D, Pendl T, Andryushkova A, et al. A histone point mutation that switches on autophagy. Autophagy. 2014;10(6):1143-5

105. Eisenberg T, Schroeder S, Andryushkova A, Pendl T, Kuttner V, Bhukel A, et al. Nucleocytosolic depletion of the energy metabolite acetyl-coenzyme a stimulates autophagy and prolongs lifespan. Cell Metab. 2014;19(3):431-44.

106. Cevenini E, Monti D, Franceschi C. Inflamm-ageing. Curr Opin Clin Nutr Metab Care. 2013;16(1):14-20.

107. Thorburn AN, Macia L, Mackay CR. Diet, metabolites, and "western-lifestyle" inflammatory diseases. Immunity. 2014;40(6):833-42.

108. Teperino R, Schoonjans K, Auwerx J. Histone methyl transferases and demethylases; can they link metabolism and transcription? Cell Metab. 2010;12(4):321-7.

109. Bonuccelli G, Tsirigos A, Whitaker-Menezes D, Pavlides S, Pestell RG, Chiavarina $B$, et al. Ketones and lactate "fuel" tumor growth and metastasis: evidence that epithelial cancer cells use oxidative mitochondrial metabolism. Cell Cycle. 2010;9(17):3506-14.

110. Martinez-Outschoorn UE, Prisco M, Ertel A, Tsirigos A, Lin Z, Pavlides S, et al. Ketones and lactate increase cancer cell "stemness", driving recurrence, metastasis and poor clinical outcome in breast cancer: achieving personalized medicine via metabolo-genomics. Cell Cycle. 2011;10(8):1271-86.

111. Figueroa ME, Abdel-Wahab O, Lu C, Ward PS, Patel J, Shih A, et al. Leukemic IDH1 and IDH2 mutations result in a hypermethylation phenotype, disrupt TET2 function, and impair hematopoietic differentiation. Cancer Cell. 2010;18(6):553-67.

112. Wellen KE, Hatzivassiliou G, Sachdeva UM, Bui TV, Cross JR, Thompson CB. ATP-citrate lyase links cellular metabolism to histone acetylation. Science. 2009;324(5930):1076-80.

113. Rathmell JC, Newgard CB. Biochemistry: a glucose-to-gene link. Science. 2009:324(5930):1021-2.

114. Katada S, Imhof A, Sassone-Corsi P. Connecting threads: epigenetics and metabolism. Cell. 2012;148(1-2):24-8.

115. Feng D, Lazar MA. Clocks, metabolism, and the epigenome. Mol Cell. 2012;47(2):158-67.

116. Kirchner $\mathrm{H}$, Osler ME, Krook A, Zierath JR. Epigenetic flexibility in metabolic regulation: disease cause and prevention? Trends Cell Biol. 2012;23(5):203-9.

117. Herzog VA, Lempradl A, Trupke J, Okulski H, Altmutter C, Ruge F, et al. A strand-specific switch in noncoding transcription switches the function of a Polycomb/Trithorax response element. Nat Genet. 2014;46(9):973-81.

118. Rinn JL. IncRNAs: linking RNA to chromatin. Cold Spring Harb Perspect Biol. 2014;6(8). doi:10.1101/cshperspect.a018614.

119. Peschansky VJ, Wahlestedt C. Non-coding RNAs as direct and indirect modulators of epigenetic regulation. Epigenetics. 2014;9(1):3-12.

120. Romagnolo DF, Zempleni J, Selmin OI. Nuclear receptors and epigenetic regulation: opportunities for nutritional targeting and disease prevention. Adv Nutr. 2014;5(4):373-85.

121. Arrowsmith CH, Bountra C, Fish PV, Lee K, Schapira M. Epigenetic protein families: a new frontier for drug discovery. Nat Rev Drug Discov. 2012;11 (5):384-400.

122. Shirodkar AV, Marsden PA. Epigenetics in cardiovascular disease. Curr Opin Cardiol. 2011;26(3):209-15.

123. Ordovas JM, Smith CE. Epigenetics and cardiovascular disease. Nat Rev Cardiol. 2010;7(9):510-9.
124. Salminen A, Kauppinen A, Hiltunen M, Kaarniranta K. Krebs cycle intermediates regulate DNA and histone methylation: epigenetic impact on the aging process. Ageing Res Rev. 2014;16C:45-65.

125. Salminen A, Kaarniranta K, Hiltunen M, Kauppinen A. Krebs cycle dysfunction shapes epigenetic landscape of chromatin: novel insights into mitochondrial regulation of aging process. Cell Signal. 2014;26 (7):1598-603

126. Pazienza V, Borghesan M, Mazza T, Sheedfar F, Panebianco C, Williams R, et al. SIRT1-metabolite binding histone macroH2A1.1 protects hepatocytes against lipid accumulation. Aging (Albany NY). 2014;6(1):35-47.

127. Sheedfar F, Vermeer M, Pazienza V, Villarroya J, Rappa F, Cappello F, et al. Genetic ablation of macrohistone H2A1 leads to increased leanness, glucose tolerance and energy expenditure in mice fed a high-fat diet. Int J Obes (Lond). 2014;39(2):331-8.

128. Ward PS, Thompson CB. Metabolic reprogramming: a cancer hallmark even Warburg did not anticipate. Cancer Cell. 2012;21(3):297-308

129. Hitchler MJ, Domann FE. Metabolic defects provide a spark for the epigenetic switch in cancer. Free Radic Biol Med. 2009;47(2):115-27.

130. Wang $\mathrm{X}$, Jin $\mathrm{H}$. The epigenetic basis of the Warburg effect. Epigenetics. 2010;5(7):566-8

131. Liu X, Wang X, Zhang J, Lam EK, Shin VY, Cheng AS, et al. Warburg effect revisited: an epigenetic link between glycolysis and gastric carcinogenesis. Oncogene. 2010;29(3):442-50

132. Kaelin Jr WG, McKnight SL. Influence of metabolism on epigenetics and disease. Cell. 2013;153(1):56-69.

133. Lu C, Thompson CB. Metabolic regulation of epigenetics. Cell Metab. 2012;16(1):9-17.

134. McCarthy N. Metabolism: unmasking an oncometabolite. Nature Rev. 2012;12(4):229.

135. Chowdhury R, Yeoh KK, Tian YM, Hillringhaus L, Bagg EA, Rose NR, et al. The oncometabolite 2-hydroxyglutarate inhibits histone lysine demethylases. EMBO Rep. 2011;12(5):463-9.

136. Waterfall JJ, Keith Killian J, Meltzer PS. The role of mutation of metabolismrelated genes in genomic hypermethylation. Biochem Biophys Res Commun. 2014;455(1-2):16-23.

137. Menendez JA, Alarcón T, Joven J. Gerometabolites: the pseudohypoxic aging side of cancer oncometabolites. Cell Cycle. 2014;13(5):699-709.

138. Wu LE, Gomes AP, Sinclair DA. Geroncogenesis: metabolic changes during aging as a driver of tumorigenesis. Cancer Cell. 2014;25(1):12-9.

139. Joven J, Rull A, Rodriguez-Gallego E, Camps J, Riera-Borrull M, HernándezAguilera A, et al. Multifunctional targets of dietary polyphenols in disease: a case for the chemokine network and energy metabolism. Food Chem Toxicol. 2013;51:267-79.

140. Huang J, Plass C, Gerhauser C. Cancer chemoprevention by targeting the epigenome. Curr Drug Targets. 2011;12(13):1925-56.

141. Vel Szic KS, Ndlovu MN, Haegeman G, Vanden Berghe W. Nature or nurture: let food be your epigenetic medicine in chronic inflammatory disorders. Biochem Pharmacol. 2010;80(12):1816-32.

142. Miceli M, Bontempo P, Nebbioso A, Altucci L. Natural compounds in epigenetics: a current view. Food Chem Toxicol. 2014;73:71-83.

143. Remely M, Lovrecic $L$, de la Garza AL, Migliore L, Peterlin B, Milagro Fl, et al. Therapeutic perspectives of epigenetically active nutrients. Br J Pharmacol. 2014. doi:10.1111/bph.12854.

144. Cooney CA. Germ cells carry the epigenetic benefits of grandmother's diet. Proc Natl Acad Sci U S A. 2006;103(46):17071-2.

145. Weaver IC. Shaping adult phenotypes through early life environments. Birth Defects Res C Embryo Today. 2009;87(4):314-26.

146. Burdge GC, Lillycrop KA. Nutrition, epigenetics, and developmental plasticity: implications for understanding human disease. Annu Rev Nutr. 2010;30:315-39.

147. Aguilera O, Fernandez AF, Munoz A, Fraga MF. Epigenetics and environment: a complex relationship. J Appl Physiol. 2010;109(1):243-51.

148. Youngson NA, Whitelaw E. Transgenerational epigenetic effects. Annu Rev Genomics Hum Genet. 2008;9:233-57.

149. Gallou-Kabani C, Vige A, Gross MS, Junien C. Nutri-epigenomics: lifelong remodelling of our epigenomes by nutritional and metabolic factors and beyond. Clin Chem Lab Med. 2007:45(3):321-7.

150. Gluckman PD, Hanson MA, Buklijas T. A conceptual framework for the developmental origins of health and disease. J Dev Orig Health Dis. 2010;1(1):6-18. 
151. Anway MD, Cupp AS, Uzumcu M, Skinner MK. Epigenetic transgenerational actions of endocrine disruptors and male fertility. Science. 2005;308(5727):1466-9.

152. Anway MD, Skinner MK. Epigenetic transgenerational actions of endocrine disruptors. Endocrinology. 2006;147(6 Suppl):S43-9.

153. Jirtle RL, Skinner MK. Environmental epigenomics and disease susceptibility. Nat Rev Genet. 2007;8(4):253-62.

154. Barker DJ, Martyn CN. The maternal and fetal origins of cardiovascular disease. J Epidemiol Community Health. 1992;46(1):8-11.

155. Jackson AA, Burdge GC, Lillycrop KA. Diet, nutrition and modulation of genomic expression in fetal origins of adult disease. World Rev Nutr Diet. 2010;101:56-72.

156. Chmurzynska A. Fetal programming: link between early nutrition, DNA methylation, and complex diseases. Nutr Rev. 2010;68(2):87-98.

157. Kaminsky ZA, Tang T, Wang SC, Ptak C, Oh GH, Wong AH, et al. DNA methylation profiles in monozygotic and dizygotic twins. Nat Genet. 2009;41(2):240-5

158. Petronis A. Epigenetics and twins: three variations on the theme. Trends Genet. 2006;22(7):347-50

159. Castillo-Fernandez JE, Spector TD, Bell JT. Epigenetics of discordant monozygotic twins: implications for disease. Genome Med. 2014;6(7):60.

160. Li CC, Cropley JE, Cowley MJ, Preiss T, Martin DI, Suter CM. A sustained dietary change increases epigenetic variation in isogenic mice. PLoS Genet. 2011;7(4):e1001380.

161. Cropley JE, Dang TH, Martin DI, Suter CM. The penetrance of an epigenetic trait in mice is progressively yet reversibly increased by selection and environment. Proc Biol Sci. 2012;279(1737):2347-53.

162. Pembrey M, Saffery R, Bygren LO. Human transgenerational responses to early-life experience: potential impact on development, health and biomedical research. J Med Genet. 2014;51(9):563-72.

163. Dolinoy DC, Weidman JR, Waterland RA, Jirtle RL. Maternal genistein alters coat color and protects Avy mouse offspring from obesity by modifying the fetal epigenome. Environ Health Perspect. 2006;114(4):567-72.

164. Dolinoy DC, Jirtle RL. Environmental epigenomics in human health and disease. Environ Mol Mutagen. 2008:49(1):4-8.

165. Waterland RA. Is epigenetics an important link between early life events and adult disease? Horm Res. 2009;71 Suppl 1:13-6.

166. Badger TM, Ronis MJ, Wolff G, Stanley S, Ferguson M, Shankar K, et al. Soy protein isolate reduces hepatosteatosis in yellow Avy/a mice without altering coat color phenotype. Exp Biol Med. 2008;233(10):1242-54.

167. Rosenfeld CS, Sieli PT, Warzak DA, Ellersieck MR, Pennington KA, Roberts RM. Maternal exposure to bisphenol $A$ and genistein has minimal effect on $A$ (vy)/a offspring coat color but favors birth of agouti over nonagouti mice. Proc Natl Acad Sci U S A. 2013;110(2):537-42.

168. Vandegehuchte MB, Lemiere F, Vanhaecke L, Vanden Berghe W, Janssen CR. Direct and transgenerational impact on Daphnia magna of chemicals with a known effect on DNA methylation. Comparative Biochem Physiol Toxicol Pharmacol. 2010;151(3):278-85.

169. Gabor Miklos GL, Maleszka R. Epigenomic communication systems in humans and honey bees: from molecules to behavior. Horm Behav. 2010;59 (3):399-406.

170. Kucharski R, Maleszka J, Foret S, Maleszka R. Nutritional control of reproductive status in honeybees via DNA methylation. Science. 2008;319 (5871):1827-30

171. Maleszka R. Epigenetic integration of environmental and genomic signals in honey bees: the critical interplay of nutritional, brain and reproductive networks. Epigenetics. 2008;3(4):188-92.

172. Foret S, Kucharski R, Pittelkow Y, Lockett GA, Maleszka R. Epigenetic regulation of the honey bee transcriptome: unravelling the nature of methylated genes. BMC Genomics. 2009;10:472.

173. Foret S, Kucharski R, Pellegrini M, Feng S, Jacobsen SE, Robinson GE, et al. DNA methylation dynamics, metabolic fluxes, gene splicing, and alternative phenotypes in honey bees. Proc Natl Acad Sci U S A. 2012;109(13):4968-73.

174. Kamakura M. Royalactin induces queen differentiation in honeybees. Nature. 2011:473(7348):478-83

175. Münch D, Amdam GV. The curious case of aging plasticity in honey bees. FEBS Lett. 2010;584(12):2496-503.

176. Li X, Huang C, Xue Y. Contribution of lipids in honeybee (Apis mellifera) royal jelly to health. J Med Food. 2013;16(2):96-102.

177. Painter RC, Osmond C, Gluckman P, Hanson M, Phillips DI, Roseboom TJ. Transgenerational effects of prenatal exposure to the Dutch famine on neonatal adiposity and health in later life. BJOG. 2008;115(10):1243-9.
178. Lumey LH, Stein AD. Transgenerational effects of prenatal exposure to the Dutch famine. BJOG. 2009;116(6):868. author reply 868.

179. Roseboom T, de Rooij S, Painter R. The Dutch famine and its long-term consequences for adult health. Early Hum Dev. 2006;82(8):485-91.

180. Whitelaw E. Epigenetics: sins of the fathers, and their fathers. Eur J Hum Genet. 2006;14(2):131-2.

181. Kaati G, Bygren LO, Edvinsson S. Cardiovascular and diabetes mortality determined by nutrition during parents' and grandparents' slow growth period. Eur J Hum Genet. 2002;10(11):682-8.

182. Hanson MA, Gluckman PD. Developmental processes and the induction of cardiovascular function: conceptual aspects. J Physiol. 2005;565(Pt 1):27-34.

183. Pons D, de Vries FR, van den Elsen PJ, Heijmans BT, Quax PH, Jukema JW. Epigenetic histone acetylation modifiers in vascular remodelling: new targets for therapy in cardiovascular disease. Eur Heart J. 2009;30(3):266-77.

184. Kim M, Long TI, Arakawa K, Wang R, Yu MC, Laird PW. DNA methylation as a biomarker for cardiovascular disease risk. PLoS One. 2010;5(3):e9692.

185. Zaina S, Heyn H, Carmona FJ, Varol N, Sayols S, Condom E, et al. A DNA methylation map of human atherosclerosis. Circ Cardiovasc Genet. 2014;7(5):692-700.

186. Waldo SW, Li Y, Buono C, Zhao B, Billings EM, Chang J, et al. Heterogeneity of human macrophages in culture and in atherosclerotic plaques. Am J Pathol. 2008;172(4):1112-26.

187. Lund G, Zaina S. Atherosclerosis risk factors can impose aberrant DNA methylation patterns: a tale of traffic and homocysteine. Curr Opin Lipidol. 2009;20(5):448-9.

188. Lund G, Zaina S. Epigenetics, transgenerational effects and risk factors for atherosclerosis. Curr Opin Lipidol. 2009;20(2):150-1.

189. Wierda RJ, Geutskens SB, Jukema JW, Quax PH, van den Elsen PJ. Epigenetics in atherosclerosis and inflammation. J Cell Mol Med. 2010;14(6A):1225-40.

190. Yang X, Wang $X$, Liu D, Yu L, Xue B, Shi H. Epigenetic regulation of macrophage polarization by DNA methyltransferase 3b. Mol Endocrinol. 2014;28(4):565-74.

191. Kittan NA, Allen RM, Dhaliwal A, Cavassani KA, Schaller M, Gallagher KA, et al. Cytokine induced phenotypic and epigenetic signatures are key to establishing specific macrophage phenotypes. PLoS One. 2013;8(10):e78045.

192. Van den Bossche J, Neele AE, Hoeksema MA, de Heij F, Boshuizen MC, van der Velden $\mathrm{S}$, et al. Inhibiting epigenetic enzymes to improve atherogenic macrophage functions. Biochem Biophys Res Commun. 2014;455(3-4):396-402.

193. Sharma P, Senthilkumar RD, Brahmachari V, Sundaramoorthy E, Mahajan A, Sharma A, et al. Mining literature for a comprehensive pathway analysis: a case study for retrieval of homocysteine related genes for genetic and epigenetic studies. Lipids Health Dis. 2006;5:1.

194. Chen NC, Yang F, Capecci LM, Gu Z, Schafer Al, Durante W, et al. Regulation of homocysteine metabolism and methylation in human and mouse tissues. FASEB J. 2010;24(8):2804-17.

195. Jiang Y, Sun T, Xiong J, Cao J, Li G, Wang S. Hyperhomocysteinemia-mediated DNA hypomethylation and its potential epigenetic role in rats. Acta Biochim Biophys Sin (Shanghai). 2007;39(9):657-67.

196. Kim JM, Hong K, Lee JH, Lee S, Chang N. Effect of folate deficiency on placental DNA methylation in hyperhomocysteinemic rats. J Nutr Biochem. 2009:20(3):172-6.

197. Bistulfi G, Vandette E, Matsui S, Smiraglia DJ. Mild folate deficiency induces genetic and epigenetic instability and phenotype changes in prostate cancer cells. BMC Biol. 2010;8:6.

198. Ghoshal K, Li X, Datta J, Bai S, Pogribny I, Pogribny M, et al. A folate- and methyl-deficient diet alters the expression of DNA methyltransferases and methyl CPG binding proteins involved in epigenetic gene silencing in livers of F344 rats. J Nutr. 2006;136(6):1522-7.

199. Ulrich CM, Reed MC, Nijhout HF. Modeling folate, one-carbon metabolism, and DNA methylation. Nutr Rev. 2008;66 Suppl 1:S27-30.

200. Pogribny IP, Tryndyak VP, Muskhelishvili L, Rusyn I, Ross SA. Methyl deficiency, alterations in global histone modifications, and carcinogenesis. J Nutr. 2007;137(1 Suppl):216S-22

201. Gerhauser C. Cancer chemoprevention and nutriepigenetics: state of the art and future challenges. Top Curr Chem. 2013;329:73-132.

202. Christodoulou M, Thomas A, Poulain S, Vidakovic M, Lahtela-Kakkonen M Matulis D, et al. Can we use the epigenetic bioactivity of caloric restriction and phytochemicals to promote healthy ageing? Med Chem Commun. 2014;5(12):1804-20. 
203. Manach C, Mazur A, Scalbert A. Polyphenols and prevention of cardiovascular diseases. Curr Opin Lipidol. 2005;16(1):77-84.

204. Fisher ND, Hollenberg NK. Aging and vascular responses to flavanol-rich cocoa. J Hypertens. 2006;24(8):1575-80.

205. Sies H, Schewe T, Heiss C, Kelm M. Cocoa polyphenols and inflammatory mediators. Am J Clin Nutrit. 2005:81(1 Suppl):304S-12.

206. Heiss C, Kleinbongard P, Dejam A, Perre S, Schroeter H, Sies H, et al. Acute consumption of flavanol-rich cocoa and the reversal of endothelial dysfunction in smokers. J Am Coll Cardiol. 2005;46(7):1276-83.

207. Baur JA, Sinclair DA. Therapeutic potential of resveratrol: the in vivo evidence. Nat Rev Drug Discov. 2006;5(6):493-506.

208. Bertelli AA, Das DK. Grapes, wines, resveratrol, and heart health. J Cardiovasc Pharmacol. 2009;54(6):468-76.

209. Chiva-Blanch G, Badimon L, Estruch R. Latest evidence of the effects of the Mediterranean diet in prevention of cardiovascular disease. Curr Atheroscler Rep. 2014;16(10):446.

210. Turunen MP, Aavik E, Yla-Herttuala S. Epigenetics and atherosclerosis. Biochim Biophys Acta. 2009;1790(9):886-91.

211. van Straten EM, Bloks WW, Huijkman NC, Baller JF, Meer H, Lutjohann D, et al. The liver $\mathrm{X}$-receptor gene promoter is hypermethylated in a mouse model of prenatal protein restriction. Am J Physiol Regul Integr Comp Physiol. 2010;298(2):R275-82.

212. Burdge GC, Slater-Jefferies J, Torrens C, Phillips ES, Hanson MA, Lillycrop KA. Dietary protein restriction of pregnant rats in the F0 generation induces altered methylation of hepatic gene promoters in the adult male offspring in the F1 and F2 generations. Br J Nutr. 2007;97(3):435-9.

213. Lillycrop KA, Phillips ES, Jackson AA, Hanson MA, Burdge GC. Dietary protein restriction of pregnant rats induces and folic acid supplementation prevents epigenetic modification of hepatic gene expression in the offspring. J Nutr. 2005;135(6):1382-6.

214. De Santa F, Totaro MG, Prosperini E, Notarbartolo S, Testa G, Natoli G. The histone $\mathrm{H} 3$ lysine-27 demethylase Jmjd3 links inflammation to inhibition of Polycomb-mediated gene silencing. Cell. 2007;130 (6):1083-94.

215. Tateishi K, Okada Y, Kallin EM, Zhang Y. Role of Jhdm2a in regulating metabolic gene expression and obesity resistance. Nature. 2009:458 (7239):757-61.

216. Reddy MA, Villeneuve LM, Wang M, Lanting L, Natarajan R. Role of the lysine-specific demethylase 1 in the proinflammatory phenotype of vascular smooth muscle cells of diabetic mice. Circ Res. 2008;103(6):615-23.

217. Brasacchio D, Okabe J, Tikellis C, Balcerczyk A, George P, Baker EK, et al. Hyperglycemia induces a dynamic cooperativity of histone methylase and demethylase enzymes associated with gene-activating epigenetic marks that coexist on the lysine tail. Diabetes. 2009:58(5):1229-36.

218. El-Osta A, Brasacchio D, Yao D, Pocai A, Jones PL, Roeder RG, et al. Transient high glucose causes persistent epigenetic changes and altered gene expression during subsequent normoglycemia. J Exp Med. 2008;205 (10):2409-17.

219. Attig L, Gabory A, Junien C. Nutritional developmental epigenomics: immediate and long-lasting effects. Proc Nutrit Soc. 2010;69(2):221-31.

220. Gallou-Kabani C, Junien C. Nutritional epigenomics of metabolic syndrome: new perspective against the epidemic. Diabetes. 2005;54(7):1899-906.

221. Karemaker R, Karemaker JM, Kavelaars A, Tersteeg-Kamperman M, Baerts W, Veen $\mathrm{S}$, et al. Effects of neonatal dexamethasone treatment on the cardiovascular stress response of children at school age. Pediatrics. 2008;122(5):978-87.

222. Barres R, Osler ME, Yan J, Rune A, Fritz T, Caidahl K, et al. Non-CpG methylation of the PGC-1alpha promoter through DNMT3B controls mitochondrial density. Cell Metab. 2009;10(3):189-98.

223. Plagemann A, Roepke K, Harder T, Brunn M, Harder A, Wittrock-Staar M, et al. Epigenetic malprogramming of the insulin receptor promoter due to developmental overfeeding. J Perinat Med. 2010;8(4):393-400.

224. Plagemann A, Harder T, Brunn M, Harder A, Roepke K, Wittrock-Staar M, et al. Hypothalamic proopiomelanocortin promoter methylation becomes altered by early overfeeding: an epigenetic model of obesity and the metabolic syndrome. J Physiol. 2009;587(Pt 20):4963-76.

225. Burdge GC, Lillycrop KA, Jackson AA. Nutrition in early life, and risk of cancer and metabolic disease: alternative endings in an epigenetic tale? Br J Nutr. 2009;101(5):619-30.

226. De Assis S, Hilakivi-Clarke L. Timing of dietary estrogenic exposures and breast cancer risk. Ann N Y Acad Sci. 2006;1089:14-35.
227. Guerrero-Bosagna CM, Sabat P, Valdovinos FS, Valladares LE, Clark SJ. Epigenetic and phenotypic changes result from a continuous pre and post natal dietary exposure to phytoestrogens in an experimental population of mice. BMC Physiol. 2008:8:17.

228. Hunter $P$. We are what we eat: the link between diet, evolution and non-genetic inheritance. EMBO Rep. 2008;9(5):413-5.

229. Waterland RA, Travisano M, Tahiliani KG, Rached MT, Mirza S. Methyl donor supplementation prevents transgenerational amplification of obesity. Int J Obes (Lond). 2008;32(9):1373-9.

230. Waterland RA, Jirtle RL. Early nutrition, epigenetic changes at transposons and imprinted genes, and enhanced susceptibility to adult chronic diseases. Nutrition. 2004;20(1):63-8.

231. Kirk H, Cefalu WT, Ribnicky D, Liu Z, Eilertsen KJ. Botanicals as epigenetic modulators for mechanisms contributing to development of metabolic syndrome. Metab Clin Exp. 2008;57(7 Suppl 1):S16-23.

232. Surani MA, Ancelin K, Hajkova $P$, Lange UC, Payer B, Western $P$, et al. Mechanism of mouse germ cell specification: a genetic program regulating epigenetic reprogramming. Cold Spring Harb Symp Quant Biol. 2004;69:1-9.

233. Hajkova P, Ancelin K, Waldmann T, Lacoste N, Lange UC, Cesari F, et al. Chromatin dynamics during epigenetic reprogramming in the mouse germ line. Nature. 2008;452(7189):877-81.

234. Wossidlo M, Nakamura T, Lepikhov K, Marques CJ, Zakhartchenko V, Boiani $\mathrm{M}$, et al. 5-Hydroxymethylcytosine in the mammalian zygote is linked with epigenetic reprogramming. Nat Commun. 2011;2:241.

235. Chong S, Youngson NA, Whitelaw E. Heritable germline epimutation is not the same as transgenerational epigenetic inheritance. Nat Genet. 2007;39 (5):574-5. author reply 575-576.

236. Blewitt ME, Vickaryous NK, Paldi A, Koseki H, Whitelaw E. Dynamic reprogramming of DNA methylation at an epigenetically sensitive allele in mice. PLoS Genet. 2006;2(4):e49.

237. Bracken AP, Helin K. Polycomb group proteins: navigators of lineage pathways led astray in cancer. Nat Rev. 2009;9(11):773-84

238. Yang L, Lin C, Liu W, Zhang J, Ohgi KA, Grinstein JD, et al. Rosenfeld MG: ncRNA- and PC2 methylation-dependent gene relocation between nuclear structures mediates gene activation programs. Cell. 2011;147(4):773-88.

239. Kogo R, Shimamura T, Mimori K, Kawahara K, Imoto S, Sudo T, et al. Long noncoding RNA HOTAIR regulates Polycomb-dependent chromatin modification and is associated with poor prognosis in colorectal cancers. Cancer Res. 2011;71(20):6320-6.

240. Morris KV, Mattick JS. The rise of regulatory RNA. Nat Rev Genet. 2014;15 (6):423-37.

241. Li Y, Kong D, Wang Z, Sarkar FH. Regulation of microRNAs by natural agents: an emerging field in chemoprevention and chemotherapy research. Pharm Res. 2010;27(6):1027-41.

242. Holoch D, Moazed D. RNA-mediated epigenetic regulation of gene expression. Nat Rev Genet. 2015;16(2):71-84

243. Ruden DM, Xiao L, Garfinkel MD, Lu X. Hsp90 and environmental impacts on epigenetic states: a model for the trans-generational effects of diethylstibesterol on uterine development and cancer. Hum Mol Genet. 2005;14 Spec No 1:R149-55.

244. Sollars V, Lu X, Xiao L, Wang X, Garfinkel MD, Ruden DM. Evidence for an epigenetic mechanism by which Hsp90 acts as a capacitor for morphological evolution. Nat Genet. 2003;33(1):70-4.

245. Ruden DM, De Luca M, Garfinkel MD, Bynum KL, Lu X. Drosophila nutrigenomics can provide clues to human gene-nutrient interactions. Annu Rev Nutr. 2005;25:499-522.

246. Dijsselbloem N, Vanden Berghe W, De Naeyer A, Haegeman G. Soy isoflavone phyto-pharmaceuticals in interleukin-6 affections: multi-purpose nutraceuticals at the crossroad of hormone replacement, anti-cancer and anti-inflammatory therapy. Biochem Pharmacol. 2004;68:1171-85.

247. Surh YJ. Cancer chemoprevention with dietary phytochemicals. Nat Rev. 2003;3(10):768-80.

248. Blanpain C, Fuchs E. Epidermal homeostasis: a balancing act of stem cells in the skin. Nat Rev Mol Cell Biol. 2009;10(3):207-17.

249. Crea F, Mathews LA, Farrar WL, Hurt EM. Targeting prostate cancer stem cells. Anticancer Agents Med Chem. 2009;9(10):1105-13.

250. Kawasaki BT, Hurt EM, Mistree T, Farrar WL. Targeting cancer stem cells with phytochemicals. Mol Interv. 2008;8(4):174-84.

251. Shytle RD, Ehrhart J, Tan J, Vila J, Cole M, Sanberg CD, et al. Oxidative stress of neural, hematopoietic, and stem cells: protection by natural compounds. Rejuvenation Res. 2007;10(2):173-8. 
252. Bickford PC, Tan J, Shytle RD, Sanberg CD, El-Badri N, Sanberg PR. Nutraceuticals synergistically promote proliferation of human stem cells. Stem Cells Dev. 2006;15(1):118-23.

253. Zhou J, Zhang H, Gu P, Bai J, Margolick JB, Zhang Y. NF-kappaB pathway inhibitors preferentially inhibit breast cancer stem-like cells. Breast Cancer Res Treat. 2008;111(3):419-27.

254. Grivennikov SI, Karin M. Inflammation and oncogenesis: a vicious connection. Curr Opin Genet Dev. 2010;20(1):65-71.

255. Aggarwal BB. Inflammation, a silent killer in cancer is not so silent! Curr Opin Pharmacol. 2009;9(4):347-50.

256. Aggarwal BB, Gehlot P. Inflammation and cancer: how friendly is the relationship for cancer patients? Curr Opin Pharmacol. 2009;9(4):351-69.

257. Anand P, Kunnumakkara AB, Sundaram C, Harikumar KB, Tharakan ST, Lai OS, et al. Cancer is a preventable disease that requires major lifestyle changes. Pharm Res. 2008;25(9):2097-116.

258. Arasaradnam RP, Commane DM, Bradburn D, Mathers JC. A review of dietary factors and its influence on DNA methylation in colorectal carcinogenesis. Epigenetics. 2008;3(4):193-8.

259. Delage B, Dashwood RH. Dietary manipulation of histone structure and function. Annu Rev Nutr. 2008;28:347-66.

260. Link A, Balaguer F, Goel A. Cancer chemoprevention by dietary polyphenols: promising role for epigenetics. Biochem Pharmacol. 2010;80(12):1771-92.

261. Folmer F, Orlikova B, Schnekenburger M, Dicato M, Diederich M. Naturally occurring regulators of histone acetylation/deacetylation. Curr Nutrit Food Sci. 2010;6:78-99.

262. Hauser AT, Jung M. Targeting epigenetic mechanisms: potential of natural products in cancer chemoprevention. Planta Med. 2008;74(13):1593-601.

263. Kontogiorgis C, Bompou E, Ntella M, Vanden Berghe W. Natural products from Mediterranean diet: from anti-inflammatory agents to dietary epigenetic modulators. Anti-Inflammatory \& Anti-Allergy Agents Med Chem. 2010;6:101-24.

264. Fang M, Chen D, Yang CS. Dietary polyphenols may affect DNA methylation. J Nutr. 2007;137(1 Suppl):223S-8.

265. Suzuki T, Miyata N. Epigenetic control using natural products and synthetic molecules. Curr Med Chem. 2006;13(8):935-58.

266. Vaquero A, Reinberg D. Calorie restriction and the exercise of chromatin. Genes Dev. 2009;23(16):1849-69.

267. Vanden Berghe W, Ndlovu MN, Hoya-Arias R, Dijsselbloem N, Gerlo S, Haegeman G. Keeping up NF-kappaB appearances: epigenetic control of immunity or inflammation-triggered epigenetics. Biochem Pharmacol. 2006;72(9):1114-31.

268. Vanden Berghe W, Sabbe L, Kaileh M, Haegeman G, Heyninck K. Molecular insight in the multifunctional activities of Withaferin A. Biochem Pharmacol. 2012;84(10):1282-91.

269. Ndlovu MN, Van Lint C, Van Wesemael K, Callebert P, Chalbos D, Haegeman $G$, et al. Hyperactivated NF-\{kappa\}B and AP-1 transcription factors promote highly accessible chromatin and constitutive transcription across the interleukin-6 gene promoter in metastatic breast cancer cells. Mol Cell Biol. 2009;29(20):5488-504.

270. Mai A, Cheng D, Bedford MT, Valente S, Nebbioso A, Perrone A, et al. Epigenetic multiple ligands: mixed histone/protein methyltransferase, acetyltransferase, and class III deacetylase (sirtuin) inhibitors. J Med Chem. 2008;51(7):2279-90.

271. Kuniyasu $\mathrm{H}$. The roles of dietary PPARgamma ligands for metastasis in colorectal cancer. PPAR Res. 2008;2008:529720.

272. Denison MS, Nagy SR. Activation of the aryl hydrocarbon receptor by structurally diverse exogenous and endogenous chemicals. Annu Rev Pharmacol Toxicol. 2003;43:309-34.

273. Darbre PD, Charles AK. Environmental oestrogens and breast cancer: evidence for combined involvement of dietary, household and cosmetic xenoestrogens. Anticancer Res. 2010;30(3):815-27.

274. Newbold RR, Padilla-Banks E, Jefferson WN. Environmental estrogens and obesity. Mol Cell Endocrinol. 2009;304(1-2):84-9.

275. Link A, Balaguer F, Shen Y, Lozano JJ, Leung HC, Boland CR, et al. Curcumin modulates DNA methylation in colorectal cancer cells. PLoS One. 2013;8(2):e57709.

276. El-Osta A. Redox mediating epigenetic changes confer metabolic memories. Circ Res. 2012;111(3):262-4

277. Zheng YG, Wu J, Chen Z, Goodman M. Chemical regulation of epigenetic modifications: opportunities for new cancer therapy. Med Res Rev. 2008;28 (5):645-87.
278. Seet BT, Dikic I, Zhou MM, Pawson T. Reading protein modifications with interaction domains. Nat Rev Mol Cell Biol. 2006;7(7):473-83.

279. Wigle TJ, Herold JM, Senisterra GA, Vedadi M, Kireev DB, Arrowsmith CH, et al. Screening for inhibitors of low-affinity epigenetic peptide-protein interactions: an AlphaScreen-based assay for antagonists of methyl-lysine binding proteins. J Biomol Screen. 2010;15(1):62-71.

280. Imai S, Guarente L. Ten years of NAD-dependent SIR2 family deacetylases: implications for metabolic diseases. Trends Pharmacol Sci. 2010;31(5):212-20.

281. Chiang EP, Wang YC, Chen WW, Tang FY. Effects of insulin and glucose on cellular metabolic fluxes in homocysteine transsulfuration, remethylation, S-adenosylmethionine synthesis, and global deoxyribonucleic acid methylation. J Clin Endocrinol Metabol. 2009;94(3):1017-25.

282. Lee $\mathrm{DH}$, Jacobs Jr DR, Porta M. Hypothesis: a unifying mechanism for nutrition and chemicals as lifelong modulators of DNA hypomethylation. Environ Health Perspect. 2009;117(12):1799-802.

283. Whittle JR, Powell MJ, Popov VM, Shirley LA, Wang C, Pestell RG. Sirtuins, nuclear hormone receptor acetylation and transcriptional regulation. Trends Endocrinol Metab. 2007;18(9):356-64.

284. Colman RJ, Beasley TM, Kemnitz JW, Johnson SC, Weindruch R, Anderson RM. Caloric restriction reduces age-related and all-cause mortality in rhesus monkeys. Nat Commun. 2014;5:3557.

285. Colman RJ, Anderson RM, Johnson SC, Kastman EK, Kosmatka KJ, Beasley TM, et al. Caloric restriction delays disease onset and mortality in rhesus monkeys. Science. 2009;325(5937):201-4.

286. Hubbard BP, Sinclair DA. Small molecule SIRT1 activators for the treatment of aging and age-related diseases. Trends Pharmacol Sci. 2014;35(3):146-54.

287. Barrajon-Catalan E, Herranz-Lopez M, Joven J, Segura-Carretero A, AlonsoVillaverde C, Menendez JA, et al. Molecular promiscuity of plant polyphenols in the management of age-related diseases: far beyond their antioxidant properties. Adv Exp Med Biol. 2014;824:141-59.

288. Howitz KT, Sinclair DA. Xenohormesis: sensing the chemical cues of other species. Cell. 2008;133(3):387-91.

289. Ivanov M, Kacevska M, Ingelman-Sundberg M. Epigenomics and interindividual differences in drug response. Clin Pharmacol Ther. 2012;92(6):727-36.

290. Schilsky RL. Personalized medicine in oncology: the future is now. Nat Rev Drug Discov. 2010;9(5):363-6.

291. Lowsky DJ, Olshansky SJ, Bhattacharya J, Goldman DP. Heterogeneity in healthy aging. J Gerontol A Biol Sci Med Sci. 2013;69(6):640-9.

292. Manach C, Donovan JL. Pharmacokinetics and metabolism of dietary flavonoids in humans. Free Radic Res. 2004;38(8):771-85.

293. Manach C, Williamson G, Morand C, Scalbert A, Remesy C. Bioavailability and bioefficacy of polyphenols in humans. I. Review of 97 bioavailability studies. Am J Clin Nutr. 2005;81(1 Suppl):230S-42.

294. Manach C, Scalbert A, Morand C, Remesy C, Jimenez L. Polyphenols: food sources and bioavailability. Am J Clin Nutr. 2004;79(5):727-47.

295. Williamson G, Manach C. Bioavailability and bioefficacy of polyphenols in humans. II. Review of 93 intervention studies. Am J Clin Nutr. 2005;81 (1 Suppl):243S-55.

296. Gasper AV, Al-Janobi A, Smith JA, Bacon JR, Fortun P, Atherton C, et al. Glutathione S-transferase M1 polymorphism and metabolism of sulforaphane from standard and high-glucosinolate broccoli. Am J Clin Nutr. 2005;82(6):1283-91.

297. Riso P, Brusamolino A, Moro M, Porrini M. Absorption of bioactive compounds from steamed broccoli and their effect on plasma glutathione S-transferase activity. Int J Food Sci Nutr. 2009;60 Suppl 1:56-71.

298. Rideout TC, Harding SV, Mackay DS. Metabolic and genetic factors modulating subject specific LDL-C responses to plant sterol therapy. Can J Physiol Pharmacol. 2012;90(5):509-14.

299. Ivanov M, Kals M, Kacevska M, Metspalu A, Ingelman-Sundberg M, Milani L. In-solution hybrid capture of bisulfite-converted DNA for targeted bisulfite sequencing of 174 ADME genes. Nucleic Acids Res. 2013;41(6):e72.

300. Zhong XB, Leeder JS. Epigenetic regulation of ADME-related genes: focus on drug metabolism and transport. Drug Metab Dispos. 2013;41(10):1721-4.

301. Oberstadt MC, Bien-Moller S, Weitmann K, Herzog S, Hentschel K, Rimmbach $C$, et al. Epigenetic modulation of the drug resistance genes MGMT, ABCB1 and ABCG2 in glioblastoma multiforme. BMC Cancer. 2013;13:617.

302. Cascorbi I. Overlapping effects of genetic variation and epigenetics on drug response: challenges of pharmacoepigenomics. Pharmacogenomics. 2013;14(15):1807-9. 
303. Dayeh TA, Olsson AH, Volkov P, Almgren P, Ronn T, Ling C. Identification of CpG-SNPs associated with type 2 diabetes and differential DNA methylation in human pancreatic islets. Diabetologia. 2013:56(5):1036-46.

304. You JS, Jones PA. Cancer genetics and epigenetics: two sides of the same coin? Cancer Cell. 2012;22(1):9-20.

305. Heyn $\mathrm{H}$. A symbiotic liaison between the genetic and epigenetic code. Front Genet. 2014:5:113.

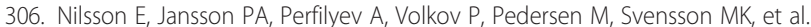
Altered DNA methylation and differential expression of genes influencing metabolism and inflammation in adipose tissue from subjects with type 2 diabetes. Diabetes. 2014;63:2962-76.

307. Heyn H, Sayols S, Moutinho C, Vidal E, Sanchez-Mut JV, Stefansson OA, et al. Linkage of DNA methylation quantitative trait loci to human cancer risk. Cell Rep. 2014;7(2):331-8.

308. Loeffler M, Kreuz M, Haake A, Hasenclever D, Trautmann H, Arnold C, et al. Genomic and epigenomic co-evolution in follicular lymphomas. Leukemia. 2014;29(2):456-63.

309. Almouzni G, Altucci L, Amati B, Ashley N, Baulcombe D, Beaujean N, et al. Relationship between genome and epigenome - challenges and requirements for future research. BMC Genomics. 2014;15:487.

310. Milenkovic D, Vanden Berghe W, Boby C, Leroux C, Declerck K, Szarc vel Szic $K$, et al. Dietary flavanols modulate the transcription of genes associated with cardiovascular pathology without changes in their DNA methylation state. PLoS One. 2014;9(4):e95527.

311. Moleres A, Campion J, Milagro Fl, Marcos A, Campoy C, Garagorri JM, et al. Differential DNA methylation patterns between high and low responders to a weight loss intervention in overweight or obese adolescents: the EVASYON study. FASEB J. 2013;27(6):2504-12

312. Bouchard L, Rabasa-Lhoret R, Faraj M, Lavoie ME, Mill J, Perusse L, et al. Differential epigenomic and transcriptomic responses in subcutaneous adipose tissue between low and high responders to caloric restriction. Am J Clin Nutr. 2010;91(2):309-20.

313. DoAmaral CL, Milagro FI, Curi R, Martinez JA. DNA methylation pattern in overweight women under an energy-restricted diet supplemented with fish oil. Biomed Res Int. 2014;2014:675021.

314. Houde AA, Hivert MF, Bouchard L. Fetal epigenetic programming of adipokines. Adipocyte. 2013;2(1):41-6.

315. Desgagne V, Hivert MF, St-Pierre J, Guay SP, Baillargeon JP, Perron P, et al Epigenetic dysregulation of the IGF system in placenta of newborns exposed to maternal impaired glucose tolerance. Epigenomics. 2014;6 (2):193-207

316. Milagro Fl, Campion J, Cordero P, Goyenechea E, Gomez-Uriz AM, Abete I, et al. A dual epigenomic approach for the search of obesity biomarkers: DNA methylation in relation to diet-induced weight loss. FASEB J. 2011;25 (4):1378-89.

317. Zierath JR, Barres RE. Nutritional status affects the epigenomic profile of peripheral blood cells. Epigenomics. 2011;3(3):259-60.

318. Wang X, Zhu H, Snieder H, Su S, Munn D, Harshfield G, et al. Obesity related methylation changes in DNA of peripheral blood leukocytes. BMC Med. 2010;8:87.

319. Franks PW, Ling C. Epigenetics and obesity: the devil is in the details. BMC Med. 2010;8:88.

320. van Kampen E, Jaminon A, van Berkel TJ, Van Eck M. Diet-induced (epigenetic) changes in bone marrow augment atherosclerosis. J Leukoc Biol. 2014;96 (5):833-41.

321. DeWoskin VA, Million RP. The epigenetics pipeline. Nat Rev Drug Discov. 2013;12(9):661-2

322. Cordero P, Milagro Fl, Campion J, Martinez JA. Supplementation with methyl donors during lactation to high-fat-sucrose-fed dams protects offspring against liver fat accumulation when consuming an obesogenic diet. J Dev Orig Health Dis. 2014;12:1-11.

323. Wong CP, Hsu A, Buchanan A, Palomera-Sanchez Z, Beaver LM, Houseman EA, et al. Effects of sulforaphane and 3,3'-diindolylmethane on genome-wide promoter methylation in normal prostate epithelial cells and prostate cancer cells. PLoS One. 2014;9(1):e86787.

324. Cho CE, Sanchez-Hernandez D, Reza-Lopez SA, Huot PS, Kim Yl, Anderson $\mathrm{GH}$. Obesogenic phenotype of offspring of dams fed a high multivitamin diet is prevented by a post-weaning high multivitamin or high folate diet Int J Obes (Lond). 2013;37(9):1177-82.

325. Bermingham EN, Bassett SA, Young W, Roy NC, McNabb WC, Cooney JM, et al. Post-weaning selenium and folate supplementation affects gene and protein expression and global DNA methylation in mice fed high-fat diets. BMC Med Genomics. 2013;6:7.

326. Langie SA, Achterfeldt S, Gorniak JP, Halley-Hogg KJ, Oxley D, van Schooten FJ, et al. Maternal folate depletion and high-fat feeding from weaning affects DNA methylation and DNA repair in brain of adult offspring. FASEB J. 2013;27(8):3323-34.

327. Hu Y, McIntosh GH, Le Leu RK, Nyskohus LS, Woodman RJ, Young GP. Combination of selenium and green tea improves the efficacy of chemoprevention in a rat colorectal cancer model by modulating genetic and epigenetic biomarkers. PLoS One. 2013;8(5):e64362.

328. Keung AJ, Joung JK, Khalil AS, Collins JJ. Chromatin regulation at the frontier of synthetic biology. Nat Rev Genet. 2015. in press. doi:10.1038/nrg3900.

329. de Groote ML, Verschure PJ, Rots MG. Epigenetic editing: targeted rewriting of epigenetic marks to modulate expression of selected target genes. Nucleic Acids Res. 2012;40(21):10596-613.

330. Paul AT, Gohil VM, Bhutani KK. Modulating TNF-alpha signaling with natural products. Drug Discov Today. 2006;11(15-16):725-32.

331. Rios JL, Recio MC, Escandell JM, Andujar I. Inhibition of transcription factors by plant-derived compounds and their implications in inflammation and cancer. Curr Pharm Des. 2009;15(11):1212-37.

332. Deorukhkar A, Krishnan S, Sethi G, Aggarwal BB. Back to basics: how natural products can provide the basis for new therapeutics. Expert Opin Investig Drugs. 2007;16(11):1753-73.

333. Khanna D, Sethi G, Ahn KS, Pandey MK, Kunnumakkara AB, Sung B, et al. Natural products as a gold mine for arthritis treatment. Curr Opin Pharmacol. 2007;7(3):344-51.

334. Bremner $P$, Heinrich M. Natural products as targeted modulators of the nuclear factor-kappaB pathway. J Pharm Pharmacol. 2002;54(4):453-72.

335. Karin M, Yamamoto Y, Wang QM. The IKK NF-kappa B system: a treasure trove for drug development. Nat Rev Drug Discov. 2004;3(1):17-26.

336. Tsai PC, Spector TD, Bell JT. Using epigenome-wide association scans of DNA methylation in age-related complex human traits. Epigenomics. 2012;4(5):511-26.

337. Murphy TM, Mill J. Epigenetics in health and disease: heralding the EWAS era. Lancet. 2014;383(9933):1952-4.

338. Szarc vel Szic K, Palagani A, Chandra Sekhar C, Diddens J, Vanden Berghe W. Connecting phytochemicals, epigenetics, and healthy aging: is metabolism the missing link? In: Rahman I, editor. Inflammation, advancing age and nutrition. Amsterdam: Elsevier; 2013. p. 111-24. ISBN 9780123978035.

339. Boonsanay V, Kim J, Braun T, Zhou Y. The emerging role of epigenetic modifiers linking cellular metabolism and gene activity in cardiac progenitor cells. Trends Cardiovasc Med. 2012;22(3):77-81.

\section{Submit your next manuscript to BioMed Central and take full advantage of:}

- Convenient online submission

- Thorough peer review

- No space constraints or color figure charges

- Immediate publication on acceptance

- Inclusion in PubMed, CAS, Scopus and Google Scholar

- Research which is freely available for redistribution 